\title{
The Immunology of SARS-CoV-2 Infection and Vaccines in Solid Organ Transplant Recipients
}

\author{
Dominika Dęborska-Materkowska ${ }^{1,+}$ and Dorota Kamińska ${ }^{2, *,+}$ (D) \\ 1 Department of Transplantation Medicine, Nephrology and Internal Diseases, Medical University of Warsaw, \\ Nowogrodzka 59, 02-006 Warsaw, Poland; dominika.deborska-materkowska@wum.edu.pl \\ 2 Department of Nephrology and Transplantation Medicine, Wroclaw Medical University, Borowska 213, \\ 50-556 Wroclaw, Poland \\ * Correspondence: dorota.kaminska@umed.wroc.pl; Tel.: +48-71-7332500 \\ + These authors contribute equally to this work and share the first authorship.
}

Citation: Dęborska-Materkowska,

D.; Kamińska, D. The Immunology of SARS-CoV-2 Infection and Vaccines in Solid Organ Transplant Recipients. Viruses 2021, 13, 1879. https:// doi.org/10.3390/v13091879

Academic Editors: Elizabeth M. Anderson and Sigrid Gouma

Received: 31 July 2021

Accepted: 17 September 2021

Published: 20 September 2021

Publisher's Note: MDPI stays neutral with regard to jurisdictional claims in published maps and institutional affiliations.

Copyright: (c) 2021 by the authors. Licensee MDPI, Basel, Switzerland. This article is an open access article distributed under the terms and conditions of the Creative Commons Attribution (CC BY) license (https:/ / creativecommons.org/licenses/by/ $4.0 /)$.

\begin{abstract}
Since its outbreak in December 2019, the coronavirus disease 2019 (COVID-19) pandemic, caused by severe acute respiratory syndrome coronavirus 2 (SARS-CoV-2), led to an enormous rise in scientific response with an excess of COVID-19-related studies on the pathogenesis and potential therapeutic approaches. Solid organ transplant (SOT) recipients are a heterogeneous population with long-lasting immunosuppression as a joining element. Immunocompromised patients are a vulnerable population with a high risk of severe infections and an increased infectionrelated mortality rate. It was postulated that the hyperinflammatory state due to cytokine release syndrome during severe COVID-19 could be alleviated by immunosuppressive therapy in SOT patients. On the other hand, it was previously established that T cell-mediated immunity, which is significantly weakened in SOT recipients, is the main component of antiviral immune responses. In this paper, we present the current state of science on COVID-19 immunology in relation to solid organ transplantation with prospective therapeutic and vaccination strategies in this population.
\end{abstract}

Keywords: solid organ transplant recipients; COVID-19; cellular immunity; humoral immunity; vaccination

\section{Introduction}

Since its outbreak in December 2019, the coronavirus disease 2019 (COVID-19), which is caused by severe acute respiratory syndrome coronavirus 2 (SARS-CoV-2) [1], has led to an enormous rise in worldwide morbidity and mortality. It was declared a pandemic by the World Health Organization (WHO) on 11 March 2020. The substantial spread of SARSCoV-2 has led to dramatic consequences for medical systems and everyday life worldwide. The pandemic elicited a vast scientific response, with an extraordinary number of recent COVID-19-related studies of its pathogenesis and potential therapeutic approaches.

Solid organ transplant (SOT) recipients are a heterogeneous population with longlasting immunosuppression. Organ transplant recipients may be in relatively good clinical condition (similar to recipients of vascularized composite allografts, pre-emptive kidney allografts, or liver allografts after acute liver failure) or present severe long-lasting native organ failure with several comorbidities (similar to heart, lung, or most previously longterm-dialyzed kidney transplant recipients).

The vast majority of SARS-CoV-2-infected patients are asymptomatic or have only mild symptoms. Approximately 5\% progress to severe COVID-19 acute respiratory distress syndrome, septic shock, and multiorgan failure [2]. Immunocompromised patients are a particularly vulnerable population with a high risk of severe infection and high infectionrelated mortality rate [3]. SOT recipients were declared a group with a high risk for severe COVID-19 [4,5]. 
Immunosuppressant drugs may leave SOT recipients more susceptible to SARS-CoV-2 infection. However, it is unclear whether incidence rates differ for SOT recipients compared to the general population. A study on liver transplant recipients in Spain found transplant recipients had almost a two-times higher risk of developing COVID-19 compared with ageand sex-matched controls [6]. Data from a British registry showed that kidney transplant recipients (KTRs) were less often infected than patients on waiting lists, but mortality was 2.5-times higher (10.2\% vs. 25.8\%) [7]. The COVID-19-related death rate among KTRs was reported to be between $17.9 \%$ and $28 \%$ [8], with even a $60 \%$ short-term fatality rate in elderly KTRs [7,9]. Recipients older than 60 years of age, with concomitant cardiovascular disease or with deteriorated kidney allograft function, had a higher mortality risk [10]. It was hypothesized that in KTRs, impairments in kidney allograft function were a more significant mortality risk factor than immunosuppressive therapy. However, a recent multicenter study reported that the risk of COVID-19-related death was 78\% higher in KTRs compared with hemodialysis patients after adequate adjustments for age, sex, frailty, and comorbidities. The mortality risk was radically higher during the first post-transplant year [11]. Results from the European Renal Association-European Dialysis and Transplant Association (ERA-EDTA) Registry from 2020 indicated that COVID-19-attributed mortality was $20.0 \%$ for patients on dialysis and $19.9 \%$ for KTRs [12].

During the first wave of the COVID-19 pandemic, the case fatality rate among hospitalized SOT recipients ranged from $13 \%$ to $29 \%$ in the initial reports [13-15], but recent data from a large, multicenter cohort study of critically ill adults with COVID-19 showed that the mortality rate of $40 \%$ in SOT recipients did not differ from $43 \%$ in the non-SOT group [16]. The authors postulated that the hyperinflammatory state that is caused by cytokine release syndrome during severe COVID-19 could be alleviated by immunosuppressive therapy in SOT patients. However, T cell-mediated immunity, which is significantly weakened in SOT recipients, is the main component of antiviral immune responses. Santeusanio reported that immunosuppression intensity and the degree of its reduction in a cohort of 38 KTRs following a COVID-19 diagnosis were not associated with mortality [8]. In a recent study of 482 SOT recipients who were hospitalized for COVID-19, the mortality rate was $20.5 \%$, which was more related to age and underlying comorbidities than to immunosuppression intensity-related factors [17]. Another matched cohort study also showed that SOT recipients who were hospitalized with COVID-19 had similar outcomes as non-SOT patients [18].

This review presents the current state of science on COVID-19 immunology with regard to solid organ transplantation and prospective therapeutic and vaccination strategies in this population.

\section{Literature Search}

The review of the literature about the immunology of SARS-CoV-2 infection and vaccines in solid organ transplant recipients was performed by both authors on PubMed with following keywords: "transplantation", "transplant", and "solid organ transplant" combined with at least one of the subsequent terms: "COVID-19", "COVID", "SARSCOV-2", "COVID19" between 01JAN2020 and 25AUG2021. Only peer-reviewed, Englishlanguage research papers were included. The additional screen of the references included in original papers to obtain supplementary studies was performed. Due to an enormous number of published papers, only a subset of the papers were cited.

\section{The Immunology of SARS-CoV-2 Infection}

2.1. Mechanism of SARS-CoV-2 Infection

SARS-CoV-2 is a positive-sense single-stranded (ss) RNA virus. It spreads mainly through the respiratory system by binding to ACE2 receptors on the surface of human cells, such as lung surfactant-producing type 2 alveolar cells (type II pneumocytes) by the SARSCoV-2 spike glycoprotein. After membrane fusion with host cells, SARS-CoV-2 releases its RNA into the cell cytoplasm, thereby allowing viral gene translation and replication [19]. 
SARS-CoV-2 is also able to infect various cells that express ACE2 receptors in many organs, leading to the involvement of the endothelium, kidney, heart, brain, liver, testes, eyes, and intestines $[20,21]$. Studies suggest that endothelium dysfunction during COVID-19 may exacerbate inflammatory and microvascular thrombotic processes [22].

\subsection{Innate Immune Response to SARS-CoV-2}

Host cells recognize specific viral molecular patterns (e.g., nucleic acids and proteins) via specific pattern recognition receptors. Endosomal viral RNA and DNA are recognized by Toll-like receptors (TLRs), and cytoplasmic viral nucleic acids are recognized by cytosolic melanoma differentiation-associated gene 5 (MDA5) receptors, retinoic-acid inducible gene I (RIG-I) receptors, and nucleotidyltransferase cyclic guanosine monophosphate-adenosine monophosphate (cGAS). This is followed by activation of the transcription factors nuclear factor $\kappa B(N F-\kappa B)$ and interferon regulatory factor 3 (IRF3), leading to the secretion of IFN- $\alpha$ and IFN- $\beta$ (IFN-I) and a wide range of proinflammatory cytokines, such as tumor necrosis factor $\alpha$ (TNF- $\alpha)$, interleukin-1 (IL-1), IL-6, and IL-18 [23]. These cytokines serve as main defense mechanisms against viral infection.

Under favorable conditions, rapid IFN-I production by infected cells occurs soon after infection, which limits viral replication within a few days [24]. Nevertheless, SARS-CoV2 has developed several mechanisms to inhibit IFN-I secretion, mainly by translational evasion and shutdown of the IFN-I-dependent induction of interferon (IFN)-stimulated genes [25-27]. Significant impairments in IFN-I signatures were observed in patients with severe COVID-19 compared to mild or moderate cases, which was associated with persistent blood viral load and an exacerbated inflammatory response [28].

The innate immune response to SARS-CoV-2 is crucial for determining the fate of COVID-19 symptomatology. SARS-CoV-2 hampers the IFN pathway and stimulates the hyperproduction of proinflammatory cytokines and chemokines via NF- $\mathrm{B}$ activation, which is conserved among COVID-19 variants [29,30]. Overall, an exuberant innate immunoinflammatory response is a hallmark of severe COVID-19.

\subsection{Cytokine Storm in COVID-19}

Cytokine storm, hyperinflammation, multiorgan failure, and acute respiratory distress syndrome were described in COVID-19 patients with high fever, dyspnea, lymphopenia, and high serum ferritin, D-dimers, C-reactive protein (CRP), and cytokines, including IL-1b, IL-6, and TNF- $\alpha[31,32]$. Several studies showed that the severity of COVID-19 symptoms positively correlated with blood levels of proinflammatory cytokines and chemokines (e.g., IL-1b, TNF- $\alpha$, monocyte chemoattractant protein 1 [MCP-1], MCP-3, cytosolic carboxypeptidase 2 [CCL2], CCL3, IL-2, sIL-2RA, IL-6, IL-7, IL-17, IL-18, granulocyte colonystimulating factor [G-CSF], interferon gamma-induced protein 10 [IP10], macrophage colony-stimulating factor [M-CSF], and microprotein 1a [MIP-1a]) and anti-inflammatory cytokines (e.g., IL-10) [33-38]. A longitudinal study showed that levels of inflammatory cytokines remained elevated in severe COVID-19 cases but declined within days in patients with moderate disease [39]. The cytokine IL-6 was shown to be a valuable biomarker of COVID-19 severity and an indicator of viral load [40,41].

In a study of 494 KTRs, elevations of inflammatory markers (CRP, lactate dehydrogenase$\mathrm{LDH}$, and procalcitonin), cardiac injury markers (hs-troponin I), and thrombosis markers (D-dimers) were significantly associated with a higher risk of COVID-19-related mortality [42]. In a retrospective matched cohort of 30 SOT recipients with COVID-19, the highest CRP, D-dimer, procalcitonin, and LDH levels did not differ from the non-transplant group. SOT patients with critical disease had higher IL-6 levels compared with those with moderate and severe disease [43]. Early elevations of CRP, hs-troponin I, D-dimer, and IL-6 were significantly associated with severe disease and mortality in KTRs [44]. Lymphopenia and high levels of ferritin and IL-6 have been reported to be predictors of mortality $[45,46]$. No studies to date have provided more detailed innate immune profiling among SOT recipients. 


\subsection{Myeloid Cells}

Driven by dendritic cells and macrophages, the dysregulated immune response to infection participates in the development of main COVID-19 syndromes. IL-1b, IL-6, and IFN-I/III from infected pulmonary epithelia contribute to macrophage activation and the further recruitment of monocytes, granulocytes, and lymphocytes from the circulation. Sustained IL- 6 and TNF- $\alpha$ release by influent monocytes causes hyperinflammation cascades and cytokine release syndrome, a secondary hemophagocytic lymphohistiocytosis-like response followed by neutrophilic NETosis and microthrombosis, the induction of pathogenic Th1 and Th17 cell responses, and the recruitment of effector immune cells. Impairments in dendritic cell migration that leads to weakened antigen presenting cell function during SARS-CoV-2 infection may result in insufficient $\mathrm{T}$ cell activation and a lower number of virus-specific T cells in the lungs $[47,48]$. Deregulated NETosis was described as one of the mechanism of neutrophils' response in viral infections and may lead to inadequately intense immune response with subsequent tissue damage. A severe COVID-19 inflammatory response contributes to a pro-NETosis state, so the potential therapies targeting NETosis (e.g., disulfiram, colchicine, dornase alfa, IL-1 receptor antagonists, anti-IL-6 etc.) potentially could decrease the risk of COVID-19 complications [49].

\subsection{Natural Killer Cells}

COVID-19 patients had a lower number of natural killer (NK) cells in peripheral blood, and high levels of IL-6 correlated with a lower number of NK cells [50]. Monocytes might impair NK cell recognition and thus kill SARS-CoV-2-infected cells. Natural killer cells are activated by immunoglobulin G1 (IgG1) and IgG3 antibodies during SARS-CoV-2 infection through Fc receptors. This suggests that antibodies that target IL-6 and TNF-signaling may restore NK cell functions in COVID-19 patients [48].

\subsection{T Cells}

$\mathrm{T}$ cells play an essential role in the antiviral response. $\mathrm{CD}^{+} \mathrm{T}$ cells kill infected cells, whereas $\mathrm{CD} 4^{+} \mathrm{T}$ cells activate $\mathrm{B}$ cells to produce antibodies. Lymphopenia with a significantly lower number of $\mathrm{CD} 4^{+} \mathrm{T}$ cells and a higher number of $\mathrm{CD} 8^{+} \mathrm{T}$ cells was described in severe COVID-19 cases, which correlated with mortality [50,51]. COVID19-related impairments in $\mathrm{CD} 4^{+} \mathrm{T}$ cells promoted the excessive activation and possible subsequent exhaustion of $\mathrm{CD}^{+} \mathrm{T}$ cells [52]. The neutrophil-to-lymphocyte ratio (NLR) and neutrophil-to-CD8 ${ }^{+} \mathrm{T}$ cell ratio (N8R) were identified as powerful prognostic factors for COVID-19 patients [53].

A lower number of $\mathrm{T}$ cells at COVID-19 onset was reported to be a marker of progression to severe disease [54]. Lower levels of $\mathrm{T}$ helper cells, $\mathrm{T}$ suppressor cells, $\mathrm{T}$ regulatory cells, and $\mathrm{CD} 16^{+} \mathrm{CD} 56^{+} \mathrm{NK}$ cells were reported in critical COVID-19 patients compared with non-critical COVID-19 patients, with impairments in the function of $\mathrm{T}$ and NK cells and very low levels of secreted cytokines [55]. However, Thieme reported that a robust anti-spike, membrane, and nucleocapsid SARS-CoV-2 protein $\mathrm{T}$ cell response was not associated with recovery in critical COVID-19 patients [56]. A spike-specific $\mathrm{CD} 4^{+}$memory $\mathrm{T}$ cell response was reported in $>90 \%$ of convalescents over 4 months after infection. CoV2-specific memory $\mathrm{CD}^{+} \mathrm{T}$ cells were detectable at $\geq 6$ months in $50 \%$ of convalescents [57]. Two months after recovery from COVID-19, patients still presented lower levels of CD4 ${ }^{+} \mathrm{T}$ cells, B cells, and granulocytes. Previously hospitalized patients presented a prolonged proinflammatory response, with the lowest levels of $\mathrm{CD} 8^{+}$regulatory $\mathrm{T}$ cells, the highest levels of $\mathrm{CD} 56^{+} \mathrm{CD} 16^{-} \mathrm{NK}$ T cells, and the promotion of a Th17-type phenotype [58].

Most studies of SOT recipients with COVID-19 also reported profound lymphopenia as in the general population [59]. The development of robust serological and functional T cell immune responses against SARS-CoV-2 was found among SOT recipients, similar to immunocompetent patients during early convalescence, with a trend toward lower SARS-CoV-2-reactive T cell frequencies [60]. 
A study of five KTRs with polymerase chain reaction (PCR)-confirmed COVID-19 found that they had reactive SARS-CoV-2-specific $\mathrm{CD} 4^{+}$and $\mathrm{CD} 8^{+} \mathrm{T}$ cells from 2 to 6 weeks after symptom onset and did not differ from patients on hemodialysis. All of them underwent a reduction of immunosuppression at the time of COVID-19 [61]. Eighteen KTRs with active COVID-19 infection had lower total lymphocytes and lower circulating memory $\mathrm{CD}^{+}$and $\mathrm{CD}^{+}{ }^{+}$cells compared with 36 matched KTRs without COVID-19. Fewer anergic and senescent $\mathrm{CD} 8^{+} \mathrm{T}$ cells were found in COVID-19 individuals, with no differences in exhausted $\mathrm{CD} 8^{+} \mathrm{T}$ cells or any $\mathrm{CD} 4^{+} \mathrm{T}$ cell subsets [62]. A detectable SARS-CoV-2-specific CD4 $4^{+} \mathrm{T}$ cell response was found in $57.1 \%$ and $47.4 \%$ of KTRs 4 and 6 months after COVID-19, respectively. The detectable SARS-CoV-2-specific CD8 ${ }^{+} \mathrm{T}$ cell response was $19.0 \%$ and $42.1 \%$ in these same cohorts [63]. In summary, the T cell-mediated anti-SARS-CoV-2 response generally did not differ from immunocompetent patients.

\subsection{B Cells}

SARS-CoV-2 provokes an immediate B cell response, with virus-specific antibody production during the first 3 weeks after symptom onset [64]. Neutralizing antibody titers are still detectable in the majority of recovered patients at least 8 months after SARSCoV-2 infection [65]. The receptor binding domain (RBD) within the S protein is highly immunogenic, and anti-RBD antibodies block virus interactions with the entry receptor, ACE2 [66].

Memory B cells are able to undergo an immediate response to reinfection by generating new high-affinity plasma cells, which are essential for long-lasting immunity. Because of the short history of COVID-19, it is not yet possible to establish the extent of the long-term memory response. While neutralizing antibody titers decline modestly overtime, with an overall half-life of 90 days over the first 8 months after infection, anti-RBD binding antibody titers remain relatively stable over 6 months [57]. Moreover, the number of spike-specific memory B cells actually increased with time after symptom onset, whereas SARS-CoV-2specific $\mathrm{CD} 4^{+} \mathrm{T}$ cells and $\mathrm{CD} 8^{+} \mathrm{T}$ cells declined, with a half-life of 3-5 months [57].

The adaptive immune response in SOT recipients generally resembles the response in immunocompetent patients, but antibody production and the T cell-mediated response may be inferior in SOT recipients. Immunosuppressive therapy as well as immune disturbances related to underlying diseases (e.g., chronic kidney disease) lead to impaired immune response to the SARS-CoV-2 infection.

SOT recipients in general are able to mount anti-SARS-CoV-2 humoral response. Higher frequencies of activated B cells were reported in COVID-19 KTRs compared with non-infected recipients [62]. In a study of 161 SOT recipients, the anti-RBD antibody response 14 days after symptom onset was present in $90 \%$ of recipients and stable over time. The length of viral shedding was not influenced by antibody presence [67]. A matched analysis of 71 liver transplant recipients and immunocompetent controls after COVID-19 showed a lower incidence of anti-nucleocapsid IgG antibodies at 3 and 6 months [68]. Therefore, compared with immunocompetent patients, liver transplant recipients had a lower prevalence of anti-SARS-CoV-2 antibodies and a more pronounced decline of antibody levels. Moreover, T cell immune responses against SARS-CoV-2 was found among SOT recipients, early after infection [60], with a detectable SARS-CoV-2-specific $\mathrm{T}$ cell response in half of the recipients 4 and 6 months after COVID-19 [63]. SARSCoV-2-reactive CD8+ T cells targeting membrane- and spike-protein were lower in SOT than in the general population. Nevertheless, polyfunctional CD8+ T cells as well as anti-nucleocapsid-protein-reactive CD8+ $\mathrm{T}$ cells did not differ significantly from nonimmunocompromised individuals [69] Another study showed no differences between SOT and non-immunocompromised convalescents regarding the distinct SARS-CoV-2-reactive $\mathrm{T}$ cell response [60]. 


\section{The Time of Viral Shedding among SOT Recipients with COVID-19}

The peak of SARS-CoV-2 viral load in infected immunocompetent individuals occurs within the first week after symptom onset. Individuals experiencing an asymptomatic SARS-CoV-2 infection have a faster viral clearance compared to symptomatic individuals [70]. The time of virus shedding was reported to be longer among immunosuppressed kidney transplant recipients (over 28 days) and corresponded to a prolonged clinical course [71]. However, prolonged SARS-CoV-2 shedding was not universal among all immunocompromised SOT recipients. The time of viral shedding was not related to the total burden of immunosuppressive therapy. It was found that only older recipients or those with multiple comorbidities (diabetes, obesity, and rheumatologic disease) consistently presented delayed SARS-CoV-2 PCR clearance [72].

Prolonged COVID-19 in immunocompromised patients can increase the risk of the development of SARS-CoV-2 escape variants that can spread in the general population. In this context, SOT recipients with persistent viral shedding may generate more transmissible or more pathogenic SARS-CoV-2 variants and thus they should be prioritized for antiCOVID-19 vaccination [73].

\section{Therapeutic Options in SOT Recipients in COVID-19}

Many therapeutic options have been studied as potentially beneficial for the treatment of COVID-19. After initial reports of success, however, most of them failed to improve patient outcomes in randomized controlled trials. To date, there have been no randomized studies among SOT recipients [74]. Reports of specific medications that were used in SOT recipients are described below.

\subsection{Antiviral Therapy in COVID-19}

Remdesivir, a nucleotide analog that resembles adenosine triphosphate (ATP) and thus inhibits virus RNA synthesis, was considered a potential treatment option for RNA viruses, including SARS-Cov-2. Initial clinical reports indicated clinical and antiviral efficacy as a part of multidrug therapy in severe COVID-19 cases [75]. However, a recent meta-analysis showed that remdesivir had no effect on mortality in hospitalized COVID-19 patients [76] but may increase the recovery percentage and decrease the ventilation requirement rate. Based on data from clinical trials, the WHO advised against remdesivir use in COVID-19. Combinations of two other antiviral drugs, lopinavir and ritonavir, were found to exert no overall beneficial effect, and their use was strongly discouraged by WHO [77].

No drug-drug interactions were found between remdesivir and immunosuppressive drugs (e.g., calcineurin inhibitors-CNI, mycophenolic acid-MPA, glucocorticoids, and mammalian/mechanistic target of rapamycin (mTOR) inhibitors).

Some small clinical trials of remdesivir use in SOT recipients were published. Fiftyseven moderate to severe COVID-19-positive KTRs received remdesivir as a part of COVID19 management. A total of $14 \%$ cases died during the study, with $1.7 \%$ graft loss. The other recipients recovered, and no major adverse events were noted for remdesivir, including liver dysfunction [78]. A multicenter cohort study of 51 KTRs with COVID-19 who were treated with remdesivir found a mortality rate of $18.9 \%$, with no significant hepatoxicity or systemic symptoms that resulted from the drug [79]. Forty-two KTRs with COVID-19 (19\% with moderate disease and $43 \%$ with severe disease) received antiretrovirals $(n=10)$ or remdesivir $(n=8)$ as part of COVID-19 management. The mortality rate was $16.6 \%$, and acute kidney injury was found in $24 \%$ of recipients at admission. The decrease in the estimated glomerular filtration rate was significantly more frequent in the remdesivir group $(80 \%)$ compared with recipients with no antiviral treatment $(29 \%)$. However, most patients exhibited the restoration of baseline kidney function within 1 month of discharge [80].

The successful management of severe COVID-19 pneumonia was reported in liver transplant recipients early after transplantation and treatment with remdesivir and convalescent plasma [81]. Another liver transplant recipient who suffered from COVID-19 with encephalopathy was successfully treated with remdesivir and convalescent plasma [82]. 
A case of a 67-year-old female with respiratory failure that was attributed to COVID-19 was described 1 year after cardiac transplantation. A reduction of immunosuppression with supportive treatment, including convalescent plasma, remdesivir, and dexamethasone, resulted in the resolution of her symptoms within days [83]. Additionally, two heart transplant recipients were successfully treated with a combination of dexamethasone and remdesivir [84].

In conclusion, remdesivir was reported to be safe in SOT recipients, but its use may result in at least the temporary worsening of kidney allograft function.

\subsection{Ivermectin}

Ivermectin, an antiparasitic drug, can potentially act upon some viruses by altering ionic balance between the internal and external environments, resulting in osmotic lysis [85]. The neurotoxicity of ivermectin, especially at high doses, may limit its clinical use. Because of biased results from clinical studies, the WHO recommended against the use of ivermectin in COVID-19 patients except in clinical trials [77]. Ivermectin is not recommended in SOT recipients because it is known as a cytochrome P450 inducer that potentially alters CNI drug levels.

\subsection{Immunotherapy to Reduce Cytokine Storm and Inflammatory-Mediated Organ Damage in COVID-19}

Patients who succumb to severe COVID-19 often present an imbalanced immune response with exacerbated inflammation and dysregulated $\mathrm{T}$ cell activation and other counteracting activities [86]. Thus, the use of anti-cytokine and immunomodulatory medication was postulated to diminish inflammatory-mediated organ damage in the general population and SOT recipients. Immunomodulation has appeared as a promising option for SOT recipients with severe COVID-19 illness, but the available evidence is mainly restricted to the anti-IL-6 drug tocilizumab [87].

The potential benefits and hazards of immunomodulatory therapeutic options for COVID-19 in the general population relative to SOT recipients are discussed below.

\subsubsection{Glucocorticoids}

Therapeutic doses of glucocorticoids affect both innate and adaptive immunity by affecting the production of proinflammatory cytokines (e.g., IL-1, IL-2, IL-6, IL-12, and IL-17), migration of macrophages/leukocytes into local inflamed sites, and regulation of Th1- and Th17-mediated cellular immunity and Th2-mediated humoral immunity. Glucocorticoids suppress cellular immunity but stimulate humoral immunity by altering the differentiation of $\mathrm{CD} 4^{+} \mathrm{T}$ cells and B cells and suppress IFN-I-mediated innate immunity by inhibiting their intracellular signaling pathways. Glucocorticoids increase the number of circulating neutrophils, enhance the opsonization of scavenger systems, and stimulate the phagocytosis of macrophages [88,89].

In COVID-19, glucocorticoids were reported to suppress virus-induced inflammation and subsequent organ damage. Dexamethasone at a dose of $6 \mathrm{mg} /$ day for up to 10 days reduced mortality in COVID-19 patients who received either invasive mechanical ventilation or oxygen alone at randomization but not in patients who received no respiratory support [90].

SOT recipients are often treated chronically with glucocorticoids at least during the peri-transplant period. Thus, the use of dexamethasone or methylprednisolone as a part of anti-SARS-CoV-2 therapy is unquestionable. Most anti-COVID-19 therapies are based on an increase in temporary doses of glucocorticoids as a part of multi-drug treatment.

A case series of four heart transplant recipients showed that they were successfully treated with dexamethasone (with the addition of remdesivir in two patients) [84]. In a cohort of 32 lung transplant recipients with moderate/severe COVID-19, the mortality rate was $34 \%$. Recipients received hydroxychloroquine ( $84 \%)$, azithromycin $(75 \%)$, augmented steroids (44\%), tocilizumab (19\%), and remdesivir (9\%) [91]. Two lung transplant recipients 
fully recovered after COVID-19-related acute respiratory distress syndrome after early treatment with high-dose corticosteroids [92].

\subsubsection{Chloroquine and Hydroxychloroquine}

Hydroxychloroquine exerts immunomodulatory effects and is widely used for the treatment of rheumatologic diseases. Hydroxychloroquine augments antigen processing for MHC class I and II presentation, directly inhibits endosomal Toll-like receptor 7 (TLR7) and TLR9, enhances the activity of regulatory T cells, and has been used as an antiviral agent. After initial enthusiasm, however, hydroxychloroquine was reported to have no beneficial effect on any stage of COVID-19 [93].

Two patients who underwent liver transplant and were infected with SARS-Cov-2 in the early post-transplant period were reported to be successfully treated with hydroxychloroquine, methylprednisolone, tocilizumab, and convalescent plasma [94]. Twentyseven lung transplant recipients with moderate/severe COVID-19 received hydroxychloroquine $(84 \%)$ in the early period of the COVID-19 pandemic, but the treatment protocol changed over time according to the new evidence of COVID-19 therapy [91]. Based on current evidence, chloroquine and hydroxychloroquine use is contraindicated in COVID-19.

\subsubsection{Anti-IL-6 Receptor Antibodies}

IL-6 is a key regulator of cytotoxic T cell, monocyte, and B cell activity. The inhibition of IL-6 reduces innate and adaptive inflammatory responses $[95,96]$.

Tocilizumab is a monoclonal antibody that targets the IL-6 receptor (both in soluble and membrane-bound forms) and thus blocks the signaling of IL-6. In COVID-19 patients, tocilizumab did not influence viral clearance or antibody production [97]. The Roche study of tocilizumab (COVACTA phase III clinical trial) did not meet its primary endpoint of improved clinical status in patients with COVID-19-associated pneumonia or the key secondary endpoint of lower patient mortality [98].

Sarilumab and siltuximab are two other human monoclonal antibodies against the IL-6 receptor. Phase III clinical trials showed no significant beneficial effects of sarilumab in COVID-19 patients [99]. One small study showed lower plasma CRP and IL-6 levels and lower mortality in COVID-19 patients who were treated with siltuximab. A small study showed that siltuximab reduced the risk of intensive care unit admission and mortality in patients with SARS-CoV-2 infection. A recently published Cochrane Database analysis of IL-6-blocking agents for treating COVID-19 showed that tocilizumab slightly reduced mortality but resulted in little or no clinical outcome improvement. Evidence of an effect of sarilumab is uncertain $[100,101]$.

Two liver transplant recipients with COVID-19 in the early post-transplant period were successfully treated with tocilizumab (and hydroxychloroquine, methylprednisolone, convalescent plasma), with no signs of graft rejection [94]. Another case series of six SOT recipients reported a mortality rate of $33 \%$, with no response to IL-6 blockade, remdesivir, and/or convalescent plasma [102].

\subsubsection{IL-1 Receptor Antagonists}

Anakinra, a recombinant IL-1 receptor antagonist, was shown in small cohort studies to improve the survival rate of COVID-19 patients [103] and respiratory function [104]. Other clinical studies also showed that treatment with anakinra reduced plasma CRP levels and improved respiratory function in COVID-19 cases [105,106]. A recent metaanalysis of 15 anakinra trials in COVID-19 patients showed a beneficial effect on lowering mortality [107].

Some pediatric liver transplant recipients successfully received anakinra as a part of multi-drug therapy [108]. A study of KTRs showed no significant effect in terms of intensive care unit admission or respiratory secondary infections between anakinra- and tocilizumab-treated groups [109]. 


\subsubsection{Anti-TNF- $\alpha$ Antibodies}

Infliximab, an anti-TNF- $\alpha$ monoclonal antibody, is widely used to treat autoimmune and inflammatory conditions. In severe COVID-19-induced cytokine storm syndrome with organ failure, infliximab was reported to exert a rapid and at least temporary decrease in proinflammatory cytokines and other inflammatory markers (e.g., CRP and LDH) with clinical improvement $[110,111]$. However, antibody responses to SARS-CoV-2 infection were shown to be attenuated in infliximab-treated patients with inflammatory bowel disease [112]. No studies of anti-TNF- $\alpha$ antibodies in the SOT population have been reported.

\subsubsection{Janus Kinase Inhibitors}

Janus kinase (JAK) signaling plays an essential role in the proinflammatory cytokinemediated immune response during infection. Ruxolitinib is a selective inhibitor of JAK1 and JAK2, reducing the activity of multiple cytokines and chemokines. In recent study of 18 COVID-19 patients, ruxolitinib was successfully used to treat the hyperinflammatory state in $55 \%$ of the patients, regardless of prior steroid or tocilizumab therapy. However, a few patients exhibited severe evolution despite ruxolitinib therapy [113].

Baricitinib is a potent inhibitor of both JAK1 and JAK2 and also an inhibitor of numbassociated kinase (AAK1), which regulates the endocytosis of cells, thereby potentially inhibiting both SARS-CoV-2 entry and proinflammatory cytokine production. In COVID-19 patients, baricitinib reduced inflammatory markers, viral load, and mortality rate, with no serious adverse events [114]. A recent meta-analysis showed that JAK inhibitors play a potential role in reducing the risk of death in people with COVID-19 [115], but no studies of SOT recipients have yet been published.

\subsection{Interferons as Therapeutics for COVID-19}

Published data suggest that IFN-I deficiency in blood could be a hallmark of severe COVID-19 [28]. Animal models suggest that that the timing of IFN activation is protective in the early phase of infection but later becomes pathologic [116] via the upregulation of ACE2 in airway epithelia [117], among other mechanisms. Treatment with IFN-I in an animal model was successful only when applied earlier than $24 \mathrm{~h}$ after infection [116].

Treatment with the antiviral drug arbidol and IFN $\alpha-1 b$ was reported to reduce the severity of illness in patients with moderate COVID-19 pneumonia [118]. A few small clinical trials in COVID-19 patients who received a subcutaneous injection of IFN-a2a or intranasal IFN- $\alpha 2 a$ or IFN- $\alpha 2 b$ reported faster recovery from the disease and faster virus clearance [119-121].

IFN $\gamma$ was initially discovered as a potent antiviral agent [122]. The intranasal administration of IFN $\gamma$ exerted a prophylactic effect in high-risk volunteers (i.e., medical workers and personnel in SARS-CoV-2 "red zones" in Russia) [123]. These authors also reported that the addition of IFN $\gamma$ to multidrug antiviral therapy stabilized patients' vital signs and resulted in no progression of pulmonary changes and no transfer to intensive care units [124].

No studies of SOT recipients have yet been published, but the use of IFN may not be advisable because of the potential risk of allograft rejection.

\subsection{Convalescent Plasma}

The efficacy of convalescent plasma therapy of COVID-19 is unclear. Although, most controlled trials have shown negative results, some studies and case reports of convalescent plasma therapy for COVID-19 have reported some effectiveness in COVID-19 patients with severe disease [125]. A recent meta-analysis showed that convalescent plasma as an adjunctive therapy could reduce the mortality rate among COVID-19 patients [126].

A case report of two liver transplant recipients reported that they were successfully treated for COVID-19 early after transplantation with convalescent plasma that was added to hydroxychloroquine, methylprednisolone, and tocilizumab [94]. Liver transplant 
recipients with severe pneumonia who received remdesivir and convalescent plasma experienced full recovery [82]. The successful treatment of three patients with convalescent donor plasma (with reduction or discontinuation of MPA in recipients) who developed severe COVID-19 directly after receiving kidney allografts was reported [127]. No acute rejection episodes after convalescent plasma therapy have been reported.

\subsection{Monoclonal Neutralizing Anti-SARS-CoV-2 Spike Protein Antibodies}

Monoclonal neutralizing antibodies bind SARS-CoV-2 spike protein and thus prevent viral attachment to ACE2 receptors. These antibodies were authorized for the treatment of high-risk patients with mild to moderate COVID-19 when administered in the early phase of infection [128]. The outcome of 16 SOT recipients (12 kidney transplant patients, one kidney-pancreas transplant patient, one kidney-liver transplant patient, and two heart transplant patients) who were given monoclonal antibodies (i.e., bamlanivimab, etesevimab, casirivimab, and imdevimab) was compared to an historical control SOT group. Neutralizing anti-SARS-CoV-2 monoclonal antibodies were shown to prevent acute respiratory failure in SOT patients with a good safety profile [129].

\subsection{Adjustment of Immunosuppression}

No randomized controlled studies have evaluated the management of chronic immunosuppression in SOT recipients with COVID-19. Based on experience with other infections, different therapeutic approaches have been proposed, with decreases in, or the discontinuation of, MPA and CNI doses and increases in corticosteroids [130]. Delayed SARS-CoV-2 PCR clearance was shown to be related to older age, multiple comorbidities, and solid organ transplant but not by overall immunosuppression burden [72]. Based on accumulating evidence, the adjustment of immunosuppression was less common during the second COVID-19 wave in Spain [131]. Various transplant society recommendations usually suggest stopping antiproliferative agents or continuing the use of standard immunosuppression [132].

Only a few episodes of acute rejections have been related to a decrease in immunosuppression, suggesting that in the case of COVID-19-related lymphopenia, the temporary cessation of CNI, MPA, or mTOR inhibitors may be safe even for 2 weeks [133]. In a cohort of 482 SOT recipients with COVID-19, acute rejection episodes occurred in only seven patients within 28 days [17]. There was one case of a kidney transplant recipient with moderate COVID-19 illness who was on belatacept-based immunosuppression and successfully received hydroxychloroquine, atazanavir, and a single dose of tocilizumab (with temporary discontinuation of MPA). Ten weeks after discharge, the patient received antithymocyte globulin, methylprednisolone, and rituximab because of biopsy-proven acute $\mathrm{T}$ cell- and antibody-mediated rejection. Four months later, the patient developed mild COVID-19 illness with a different lineage of SARS-CoV-2 [134].

Inflammatory damage can be weakened by anti-cytokine treatments. Some evidence suggests that maintenance immunosuppression agents can lessen COVID-19 symptoms. Some in vitro studies reported that the mTOR-related pathway plays an important role in the modulation of COVID-19 outcomes [135]. Based on hypothesized antiviral and immunomodulatory effects of cyclosporine, a study of KTRs showed that the discontinuation of MPA, together with a switch from tacrolimus to cyclosporine, reduced mortality with no graft function deterioration or signs of rejection [136]. One study of liver transplant recipients showed that tacrolimus dose maintenance was associated with better patient survival, which encouraged clinicians to keep the tacrolimus dose unchanged [137].

It was shown that mortality among SOT recipients was related to age and underlying comorbidities rather than immunosuppression intensity. However, in liver transplant recipients, immunosuppression that contained mycophenolate was an independent predictor of severe COVID-19, particularly at doses higher than $1000 \mathrm{mg} /$ day. Such a severe COVID-19 outcome did not occur with mTOR inhibitors or CNI, and complete immunosuppression withdrawal showed no benefit [6]. A meta-analysis of data on 202 SOT recipients with 
COVID-19 suggested that maintaining immunosuppression might be safe in moderate and severe COVID-19. Moreover, tacrolimus could be specifically beneficial [138].

Recently, published recommendations for SOT recipients consist of a general approach based on disease severity:

- Mild disease (i.e., no symptoms or symptoms of upper or lower respiratory tract infection, with no hypoxia): supportive care only, no change in maintenance immunosuppression, and consider monoclonal neutralization.

- Moderate illness (i.e., hypoxia, requiring supplemental oxygen): dexamethasone (or equivalent steroid) up to 10 days and remdesivir for 5 days, and consider reducing or holding antimetabolite.

- Severe illness (i.e., mechanical ventilation or extra corporeal membrane oxygenationECMO requirement): dexamethasone (or equivalent steroid) up to 10 days, consider remdesivir for 5 days, and consider reducing or holding antimetabolite [74].

Multi-drug therapy during the COVID-19 pandemic creates a favorable situation for many drug-drug interactions to occur. QT monitoring is mandatory when hydroxychloroquine and azithromycin are combined. Azithromycin, lopinavir/ritonavir, remdesivir, favipiravir, chloroquine, hydroxychloroquine, and tocilizumab may interact with immunosuppressive drugs. Mycophenolate potentially interacts with lopinavir/ritonavir, with a need for dose reduction and close laboratory monitoring. Sirolimus may increase the level of atazanavir, and lopinavir/ritonavir and their combination are contraindicated. CNI increases blood levels of atazanavir, lopinavir/ritonavir, chloroquine, and hydroxychloroquine and may slightly decrease tocilizumab levels. Macrolides increase CNI levels, but azithromycin exerts minimal effects on the cytochrome p450 system [139]. Nevertheless, a case of acute kidney graft injury during COVID-19 treatment with azithromycin subsequent to tacrolimus increased levels of tacrolimus because of an azithromycin interaction with p450 enzyme [140].

\section{Vaccination}

In addition to public health measures, vaccination has emerged as a key tool for controlling the ongoing pandemic. A two-dose regimen of mRNA vaccine conferred $95 \%$ protection against COVID-19. Therefore, in December 2020, multiple regulatory agencies worldwide authorized the use of mRNA vaccines for SARS-CoV-2 [141]. After the start of the promotion of SARS-CoV-2 vaccines, the number of confirmed cases worldwide per week began to decline since the beginning of 2021. Unfortunately, previous reports have not addressed the prevention of SARS-Cov-2 infection in solid organ transplant recipients that have been excluded from major SARS-CoV-2 vaccine clinical trials [142,143].

Neutralizing antibodies are the part of adaptive immunity crucial for antiviral defense. Antibodies that target the viral receptor binding domain (RBD) in the S1 domain of the SARS-CoV-2 spike protein have been shown to exhibit a virus-neutralizing capacity $[64,65,144]$. After vaccination, the highest concentrations of serum and breast milk antibodies were observed with maximum about 29 days after the second dose [145].

Studies indicate immunocompromised people mount a reduced antibody response following a primary vaccine series, compared to immunocompetent vaccine recipients [146-149]. Immunogenicity to the SARS-CoV-2 vaccination can be assessed by quantifying antibodies to the spike receptor-binding domain and evaluating cellular responses. The preliminary results focused solely on antibody measurements following the first dose of vaccine and the timing of the antibody testing was variable, which could impact results [150]. The authors observed that less than $20 \%$ of patients had detectable antibodies, with the lowest response in those receiving antiproliferative medications and older individuals. Other studies indicate that kidney transplant recipients have an even weaker anti-SARS-CoV-2 antibody response, ultimately resulting in a low seroconversion rate 6.2 to $10.8 \%$ [151,152].

Given the absence of robust data to support the use of commercially available tests for measuring vaccine responses, it has been difficult to address their concerns. The data published to date do not give us the granular detail to develop recommendations from 
individual test results. Most commercially available serological assays are qualitative or, at best, semi-quantitative. Having a positive result may mislead a patient into thinking they are "safe" from infection when in fact titers are below protective titers. Conversely, a negative result may add to patient anxiety, despite contributions from untested factors, such as cellular immune responses. Furthermore, since the thresholds for protection and the impact of cellular responses are just now being established in healthy individuals, it further confounds our understanding of how to apply results to transplant recipients.

Emerging data suggest that an additional COVID-19 vaccine dose in immunocompromised people enhances antibody response and increases the proportion who respond. In small studies, symptoms reported after the third dose were consistent with previous doses and the intensity of the symptoms was mostly mild or moderate. The prevalence of anti-SARS-CoV-2 antibodies was $0 \%$ before the first dose, $4 \%$ before the second dose, $40 \%$ before the third dose, and $68 \% 4$ weeks after the third dose [153]. Among those who had no detectable antibody response to an initial mRNA vaccine series, 33-50\% developed an antibody response to an additional dose. No serious adverse events were reported after administration of the third dose. No patients developed critical side effects requiring hospitalization [154].

There is a risk of the altered immunological response constituting a barrier in the effective vaccination against SARS-Cov- 2 in the future and the patients may require additional or double doses of the vaccine as in the case of anti-hepatitis-B vaccination [154]. Additionally, if a lower response to SARS-CoV-2 vaccines is confirmed, public health authorities and transplant providers will need to have different thresholds for when these patients may safely return to more normal activity.

These are not entirely surprising results, given that diminished antibody responses have been frequently described with other vaccines. Among kidney transplant recipients who received the influenza vaccine, only $33 \%$ of subjects reached seroprotective and seroconversion titers, with poorer responses in those less than 6 months post-transplant [155]. In another study, among a cohort of solid organ transplant recipients, a second dose does of influenza vaccine enhanced immunogenicity with a seroprotection rate after first dose of $69 \%$ versus $81 \%$ after the second dose [156]. Immune responses to viral infection in solid organ transplant recipients are not fully understood, but pioneer research indicates cell-mediated immunity is a critical factor for the control, prediction of viral replication, and recovery [157-159].

Novel immunodiagnostics to measure cellular immune response to SARS-CoV-2 are necessary to better evaluate the immune status of individuals and populations and assess emerging vaccines. Recent results indicate that SARS-CoV-2 Interferon-gamma release assay (IGRA) can be implemented in clinical laboratories to identify individuals with reactive $\mathrm{T}$ cells to SARS-CoV-2 [160]. In another study using IGRA, the authors observed that $78 \%$ of PCR-positive volunteers with undetectable antibodies showed T cell immunity against SARS-CoV-2 [161]. In the first study assessing humoral and T cell vaccine-induced responses to mRNA anti-SARSCoV2 vaccine in KTRs treated with belatacept, seroconversion occurred in very few patients, and $\mathrm{T}$ cell response in less than one-third of patients [162].

Some transplant professionals are advocating changes in patient management to improve vaccine responses, in particular the suspension of antiproliferative agents in anticipation of vaccination. However, unproven alterations in immunosuppression may ultimately be more detrimental than beneficial if changes increase the risk of rejection or provide no meaningful improvement in vaccine responses. One concern with vaccines in solid organ transplant recipients is the possible induction of alloreactivity and rejection. In one study of kidney transplant recipients, the authors showed that $12-17 \%$ of patients developed HLA alloantibody after an AS03-containing influenza vaccine. Although most of the reported anti-HLA antibodies had significantly declined or disappeared at 6 months, one patient suffered an acute antibody-mediated rejection and one developed a thrombotic 
microangiopathy [163]. In addition, a case-control study in heart transplant patients showed a significantly increased risk of rejection after the AS03 vaccine [164].

Then on the other hand, another study reported the development of de novo anti-HLA antibodies after receiving the influenza vaccine in kidney transplant recipients. Despite the fact that $60 \%$ of these antibodies were donor-specific, no episodes of antibody or cellular rejection were identified while these antibodies were detectable [155]. In addition, in a randomized trial in a wide range of transplant recipients, there was no correlation between the production of alloantibodies and influenza vaccine [165]. There is a knowledge gap regarding the immune mechanisms that confer protection against SARS-CoV-2 and the risk of acute rejection episodes in the post-vaccinated population of organ transplant recipients.

There are many indications that the adoption of the vaccine will change a lot in the peritransplant procedure and allow transplantation programs to be reopened. A few basic rules and timing of vaccination against COVID-19 in transplant recipients and candidates were proposed [132]. Due to quicker lowering of post-vaccination antibodies posttransplantation, it is anticipated that, in the case of the COVID-19 vaccine, an additional shot (or schedule) will be required. In August 2021, The Food and Drug Administration granted full approval to mRNA SARS-Cov-2 vaccine for people 16 and older. Following FDA's decision Centers for Diseases Control and Prevention recommend an additional mRNA dose for moderately to severely immunocompromised people. This includes organ transplant recipients that are taking immunosuppressive therapy.

\section{Conclusions}

All available evidence indicates that SOT recipients with moderate or severe COVID19 illness who are on chronic immunosuppressive therapy can mount SARS-CoV-2-reactive adaptive immune responses, both humoral and cellular. However, the precise immunologic characteristics of differences between immunocompromised SOT recipients and the immunocompetent population have not yet been characterized. The magnitude of the immune response to SARS-CoV-2 infection and vaccination, including kinetics and durability, should be examined. A detailed analysis of the "net state of immunosuppression" could help identify specific recipients who have a higher risk of SARS-CoV-2 infection. Such assessments may include the evaluation of not only immunosuppressive drug levels but also TTV and CMV replication, T- and B-lymphocyte subsets, soluble CD30, stimulated intracellular ATP levels, immunoglobulin, and complement levels [166].

Controlled randomized trials on anti-COVID-19 drugs as well as vaccines should also include SOT recipients to provide evidence of their efficacy in this group of patients.

Author Contributions: Conceptualization, D.D.-M. and D.K.; methodology, D.D.-M. and D.K.; resources, D.D.-M. and D.K.; writing—original draft preparation, D.D.-M. and D.K.; writing—review and editing, D.D.-M. and D.K.; visualization, D.D.-M. and D.K.; supervision, D.D.-M. and D.K. All authors have read and agreed to the published version of the manuscript.

Funding: This research received no external funding.

Institutional Review Board Statement: Not applicable.

Informed Consent Statement: Not applicable.

Data Availability Statement: Not applicable.

Conflicts of Interest: The authors declare no conflict of interest.

\section{References}

1. Gorbalenya, A.E.; Baker, S.C.; Baric, R.S.; de Groot, R.J.; Drosten, C.; Gulyaeva, A.A.; Haagmans, B.L.; Lauber, C.; Leontovich, A.M.; Neuman, B.W.; et al. The species Severe acute respiratory syndrome-related coronavirus: Classifying 2019-nCoV and naming it SARS-CoV-2. Nat. Microbiol. 2020, 5, 536-544. [CrossRef]

2. Zhou, F.; Yu, T.; Ronghui, D.; Fan, G.; Liu, Y.; Liu, Z.; Xiang, J.; Wang, Y.; Song, B.; Gu, X.; et al. Clinical course and risk factors for mortality of adult inpatients with COVID-19 in Wuhan, China: A retrospective cohort study. Lancet 2020, 395, $1054-1062$. [CrossRef] 
3. Fishman, J.A. Infection in Organ Transplantation. Am. J. Transplant 2017, 17, 856-879. [CrossRef]

4. Certain Medical Conditions and Risk for Severe COVID-19 Illness I CDC. Available online: https:/ /www.cdc.gov/coronavirus / 2019-ncov/need-extra-precautions / people-with-medical-conditions.html (accessed on 14 July 2021).

5. Fung, M.; Babik, J.M. COVID-19 in Immunocompromised Hosts: What We Know so Far. Clin. Infect. Dis. 2021, 72, 340-350. [CrossRef]

6. Colmenero, J.; Rodríguez-Perálvarez, M.; Salcedo, M.; Arias-Milla, A.; Muñoz-Serrano, A.; Graus, J.; Nuño, J.; Gastaca, M.; Bustamante-Schneider, J.; Cachero, A.; et al. Epidemiological pattern, incidence, and outcomes of COVID-19 in liver transplant patients. J. Hepatol. 2021, 74, 148-155. [CrossRef] [PubMed]

7. Crespo, M.; Pérez-Sáez, M.J.; Redondo-Pachón, D.; Llinàs-Mallol, L.; Montero, M.M.; Villar-García, J.; Arias-Cabrales, C.; Buxeda, A.; Burballa, C.; Vázquez, S.; et al. COVID-19 in elderly kidney transplant recipients. Am. J. Transplant. 2020, 20, 2883-2889. [CrossRef]

8. Santeusanio, A.D.; Menon, M.C.; Liu, C.; Bhansali, A.; Patel, N.; Mahir, F.; Rana, M.; Tedla, F.; Mahamid, A.; Fenig, Y.; et al. Influence of patient characteristics and immunosuppressant management on mortality in kidney transplant recipients hospitalized with coronavirus disease 2019 (COVID-19). Clin. Transplant. 2021, 35, e14221. [CrossRef]

9. Kędzierska-Kapuza, K.; Zielińska, D.; Matejak-Górska, M.; Durlik, M. The Course of SARS-CoV-2 in a Patient After a Recent Kidney Transplant: A Literature Review on COVID-19 Therapy. Transplant. Proc. 2021, 53, 1194-1201. [CrossRef] [PubMed]

10. Caillard, S.; Chavarot, N.; Francois, H.; Matignon, M.; Greze, C.; Kamar, N.; Gatault, P.; Thaunat, O.; Legris, T.; Frimat, L.; et al. Is COVID-19 infection more severe in kidney transplant recipients? Am. J. Transplant. 2021, 21, 1295-1303. [CrossRef]

11. Goffin, E.; Candellier, A.; Vart, P.; Noordzij, M.; Arnol, M.; Covic, A.; Lentini, P.; Malik, S.; Reichert, L.J.; Sever, M.S.; et al. COVID-19 related mortality in kidney transplant and hemodialysis patients: A comparative, prospective registry based study. Nephrol. Dial. Transplant. 2021, gfab200. [CrossRef]

12. Jager, K.J.; Kramer, A.; Chesnaye, N.C.; Couchoud, C.; Sánchez-Álvarez, J.E.; Garneata, L.; Collart, F.; Hemmelder, M.H.; Ambühl, P.; Kerschbaum, J.; et al. Results from the ERA-EDTA Registry indicate a high mortality due to COVID-19 in dialysis patients and kidney transplant recipients across Europe. Kidney Int. 2020, 98, 1540-1548. [CrossRef]

13. Pereira, M.R.; Mohan, S.; Cohen, D.J.; Husain, S.A.; Dube, G.K.; Ratner, L.E.; Arcasoy, S.; Aversa, M.M.; Benvenuto, L.J.; Dadhania, D.M.; et al. COVID-19 in solid organ transplant recipients: Initial report from the US epicenter. Am. J. Transplant 2020, 20, 1800-1808. [CrossRef]

14. Fernández-Ruiz, M.; Andrés, A.; Loinaz, C.; Delgado, J.F.; López-Medrano, F.; San Juan, R.; González, E.; Polanco, N.; Folgueira, M.D.; Lalueza, A.; et al. COVID-19 in solid organ transplant recipients: A single-center case series from Spain. Am. J. Transplant. 2020, 20, 1849-1858. [CrossRef]

15. Kolonko, A.; Dudzicz, S.; Wiecek, A.; Król, R. COVID-19 infection in solid organ transplant recipients: A single-center experience with patients immediately after transplantation. Transpl. Infect. Dis. 2021, 23, e13381. [CrossRef] [PubMed]

16. Molnar, M.Z.; Bhalla, A.; Azhar, A.; Tsujita, M.; Talwar, M.; Balaraman, V.; Sodhi, A.; Kadaria, D.; Eason, J.D.; Hayek, S.S.; et al. Outcomes of critically ill solid organ transplant patients with COVID-19 in the United States. Am. J. Transplant. 2020, 20, 3061-3071. [CrossRef] [PubMed]

17. Kates, O.S.; Haydel, B.M.; Florman, S.S.; Rana, M.M.; Chaudhry, Z.S.; Ramesh, M.S.; Safa, K.; Kotton, C.N.; Blumberg, E.A.; Besharatian, B.D.; et al. Coronavirus Disease 2019 in Solid Organ Transplant: A Multicenter Cohort Study. Clin. Infect. Dis. 2020, ciaa1097. [CrossRef]

18. Pereira, M.R.; Arcasoy, S.; Farr, M.A.; Mohan, S.; Emond, J.C.; Tsapepas, D.S.; Shi, Q.; Purpura, L.; Uhlemann, A.-C.; Zucker, J.; et al. Outcomes of COVID-19 in solid organ transplant recipients: A matched cohort study. Transpl. Infect. Dis. 2021, 23, e13637. [CrossRef] [PubMed]

19. Dezfuli, N.K.; Adcock, I.M.; Montazami, N.; Mortaz, E.; Velayati, A. Update on Immunology of COVID-19 Disease and Potential Strategy for Controlling. Tanaffos 2020, 19, 274-290.

20. Hamming, I.; Timens, W.; Bulthuis, M.L.C.; Lely, A.T.; Navis, G.J.; van Goor, H. Tissue distribution of ACE2 protein, the functional receptor for SARS coronavirus. A first step in understanding SARS pathogenesis. J. Pathol. 2004, 203, 631-637. [CrossRef]

21. To, K.F.; Lo, A.W.I. Exploring the pathogenesis of severe acute respiratory syndrome (SARS): The tissue distribution of the coronavirus (SARS-CoV) and its putative receptor, angiotensin-converting enzyme 2 (ACE2). J. Pathol. 2004, 203, 740-743. [CrossRef]

22. Bernard, I.; Limonta, D.; Mahal, L.K.; Hobman, T.C. Endothelium infection and dysregulation by sars-cov-2: Evidence and caveats in covid-19. Viruses 2021, 13, 29. [CrossRef]

23. Guo, Y.R.; Cao, Q.D.; Hong, Z.S.; Tan, Y.Y.; Chen, S.D.; Jin, H.J.; Tan, K.S.; Wang, D.Y.; Yan, Y. The origin, transmission and clinical therapies on coronavirus disease 2019 (COVID-19) outbreak- A n update on the status. Mil. Med. Res. 2020, 7, 11. [CrossRef]

24. Fung, S.-Y.; Yuen, K.-S.; Ye, Z.-W.; Chan, C.-P.; Jin, D.-Y. A tug-of-war between severe acute respiratory syndrome coronavirus 2 and host antiviral defence: Lessons from other pathogenic viruses. Emerg. Microbes Infect. 2020, 9, 558-570. [CrossRef]

25. Drappier, M.; Michiels, T. Inhibition of the OAS/RNase L pathway by viruses. Curr. Opin. Virol. 2015, 15, 19-26. [CrossRef] [PubMed]

26. Sui, L.; Zhao, Y.; Wang, W.; Wu, P.; Wang, Z.; Yu, Y.; Hou, Z.; Tan, G.; Liu, Q. SARS-CoV-2 Membrane Protein Inhibits Type I Interferon Production Through Ubiquitin-Mediated Degradation of TBK1. Front. Immunol. 2021, 12, 662989. [CrossRef] [PubMed] 
27. Hsu, J.C.C.; Laurent-Rolle, M.; Pawlak, J.B.; Wilen, C.B.; Cresswell, P. Translational shutdown and evasion of the innate immune response by SARS-CoV-2 NSP14 protein. Proc. Natl. Acad. Sci. USA 2021, 118, e2101161118. [CrossRef]

28. Hadjadj, J.; Yatim, N.; Barnabei, L.; Corneau, A.; Boussier, J.; Smith, N.; Péré, H.; Charbit, B.; Bondet, V.; Chenevier-Gobeaux, C.; et al. Impaired type I interferon activity and inflammatory responses in severe COVID-19 patients. Science 2020, 369, 718-724. [CrossRef] [PubMed]

29. Su, C.-M.; Wang, L.; Yoo, D. Activation of NF-kB and induction of proinflammatory cytokine expressions mediated by ORF7a protein of SARS-CoV-2. Sci. Rep. 2021, 11, 13464. [CrossRef]

30. Blanco-Melo, D.; Nilsson-Payant, B.E.; Liu, W.C.; Uhl, S.; Hoagland, D.; Møller, R.; Jordan, T.X.; Oishi, K.; Panis, M.; Sachs, D.; et al. Imbalanced Host Response to SARS-CoV-2 Drives Development of COVID-19. Cell 2020, 181, 1036-1045.e9. [CrossRef] [PubMed]

31. Gustine, J.N.; Jones, D. Immunopathology of Hyperinflammation in COVID-19. Am. J. Pathol. 2021, 191, 4. [CrossRef] [PubMed]

32. Yang, L.; Xie, X.; Tu, Z.; Fu, J.; Xu, D.; Zhou, Y. The signal pathways and treatment of cytokine storm in COVID-19. Signal Transduct. Target. Ther. 2021, 6, 255. [CrossRef] [PubMed]

33. Ricci, D.; Etna, M.P.; Rizzo, F.; Sandini, S.; Severa, M.; Coccia, E.M. Innate Immune Response to SARS-CoV-2 Infection: From Cells to Soluble Mediators. Int. J. Mol. Sci. 2021, 22, 7017. [CrossRef] [PubMed]

34. Chen, G.; Wu, D.; Guo, W.; Cao, Y.; Huang, D.; Wang, H.; Wang, T.; Zhang, X.; Chen, H.; Yu, H.; et al. Clinical and immunological features of severe and moderate coronavirus disease 2019. J. Clin. Investig. 2020, 130, 2620-2629. [CrossRef]

35. Melo, A.K.G.; Milby, K.M.; Caparroz, A.L.M.A.; Pinto, A.C.P.N.; Santos, R.R.P.; Rocha, A.P.; Ferreira, G.A.; Souza, V.A.; Valadares, L.D.A.; Vieira, R.M.R.A.; et al. Biomarkers of cytokine storm as red flags for severe and fatal COVID-19 cases: A living systematic review and meta-analysis. PLoS ONE 2021, 16, e0253894. [CrossRef]

36. Chi, Y.; Ge, Y.; Wu, B.; Zhang, W.; Wu, T.; Wen, T.; Liu, J.; Guo, X.; Huang, C.; Jiao, Y.; et al. Serum cytokine and chemokine profile in relation to the severity of coronavirus disease 2019 in China. J. Infect. Dis. 2020, 222, 746-754. [CrossRef] [PubMed]

37. Yang, Y.; Shen, C.; Li, J.; Yuan, J.; Wei, J.; Huang, F.; Wang, F.; Li, G.; Li, Y.; Xing, L.; et al. Plasma IP-10 and MCP-3 levels are highly associated with disease severity and predict the progression of COVID-19. J. Allergy Clin. Immunol. 2020, 146, 119-127.e4. [CrossRef]

38. Huang, C.; Wang, Y.; Li, X.; Ren, L.; Zhao, J.; Hu, Y.; Zhang, L.; Fan, G.; Xu, J.; Gu, X.; et al. Clinical features of patients infected with 2019 novel coronavirus in Wuhan, China. Lancet 2020, 395, 497-506. [CrossRef]

39. Lucas, C.; Wong, P.; Klein, J.; Castro, T.B.R.; Silva, J.; Sundaram, M.; Ellingson, M.K.; Mao, T.; Oh, J.E.; Israelow, B.; et al. Longitudinal analyses reveal immunological misfiring in severe COVID-19. Nature 2020, 584, 463-469. [CrossRef] [PubMed]

40. Velavan, T.P.; Kuk, S.; Linh, L.T.K.; Lamsfus Calle, C.; Lalremruata, A.; Pallerla, S.R.; Kreidenweiss, A.; Held, J.; Esen, M.; Gabor, J.; et al. Longitudinal monitoring of laboratory markers characterizes hospitalized and ambulatory COVID-19 patients. Sci. Rep. 2021, 11, 14471. [CrossRef]

41. Liu, Y.; Zhang, C.; Huang, F.; Yang, Y.; Wang, F.; Yuan, J.; Zhang, Z.; Qin, Y.; Li, X.; Zhao, D.; et al. Elevated plasma levels of selective cytokines in COVID-19 patients reflect viral load and lung injury. Natl. Sci. Rev. 2020, 7, 1003-1011. [CrossRef]

42. Caillard, S.; Chavarot, N.; Francois, H.; Matignon, M.; Snanoudj, R.; Tourret, J.; Greze, C.; Thaunat, O.; Frimat, L.; Westeel, P.F.; et al. Clinical utility of biochemical markers for the prediction of COVID-19-related mortality in kidney transplant recipients. Kidney Int. Rep. 2021. [CrossRef] [PubMed]

43. Ringer, M.; Azmy, V.; Kaman, K.; Tang, D.; Cheung, H.; Azar, M.M.; Price, C.; Malinis, M. A retrospective matched cohort single-center study evaluating outcomes of COVID-19 and the impact of immunomodulation on COVID-19-related cytokine release syndrome in solid organ transplant recipients. Transpl. Infect. Dis. 2021, 23, e13556. [CrossRef] [PubMed]

44. Benotmane, I.; Perrin, P.; Vargas, G.G.; Bassand, X.; Keller, N.; Lavaux, T.; Ohana, M.; Bedo, D.; Baldacini, C.; Sagnard, M.; et al. Biomarkers of Cytokine Release Syndrome Predict Disease Severity and Mortality from COVID-19 in Kidney Transplant Recipients. Transplantation 2021, 105, 158-169. [CrossRef]

45. Azzi, Y.; Bartash, R.; Scalea, J.; Loarte-Campos, P.; Akalin, E. COVID-19 and Solid Organ Transplantation: A Review Article. Transplantation 2021, 105, 37-55. [CrossRef]

46. Belsky, J.A.; Tullius, B.P.; Lamb, M.G.; Sayegh, R.; Stanek, J.R.; Auletta, J.J. COVID-19 in immunocompromised patients: A systematic review of cancer, hematopoietic cell and solid organ transplant patients. J. Infect. 2021, 82, 329-338. [CrossRef]

47. Prokunina-Olsson, L.; Alphonse, N.; Dickenson, R.E.; Durbin, J.E.; Glenn, J.S.; Hartmann, R.; Kotenko, S.V.; Lazear, H.M.; O’Brien, T.R.; Odendall, C.; et al. COVID-19 and emerging viral infections: The case for interferon lambda. J. Exp. Med. 2020, 217, e20200653. [CrossRef]

48. Vabret, N.; Britton, G.J.; Gruber, C.; Hegde, S.; Kim, J.; Kuksin, M.; Levantovsky, R.; Malle, L.; Moreira, A.; Park, M.D.; et al. Immunology of COVID-19: Current State of the Science. Immunity 2020, 52, 910-941. [CrossRef]

49. Gillot, C.; Favresse, J.; Mullier, F.; Lecompte, T.; Dogné, J.-M.; Douxfils, J. NETosis and the Immune System in COVID-19: Mechanisms and Potential Treatments. Front. Pharmacol. 2021, 12, 708302. [CrossRef]

50. Lombardi, A.; Trombetta, E.; Cattaneo, A.; Castelli, V.; Palomba, E.; Tirone, M.; Mangioni, D.; Lamorte, G.; Manunta, M.; Prati, D.; et al. Early Phases of COVID-19 Are Characterized by a Reduction in Lymphocyte Populations and the Presence of Atypical Monocytes. Front. Immunol. 2020, 11, 560330. [CrossRef] [PubMed]

51. Erdinc, B.; Sahni, S.; Gotlieb, V. Hematological manifestations and complications of COVID-19. Adv. Clin. Exp. Med. 2021, 30, 101-107. [CrossRef] 
52. Zheng, H.Y.; Zhang, M.; Yang, C.X.; Zhang, N.; Wang, X.C.; Yang, X.P.; Dong, X.Q.; Zheng, Y.T. Elevated exhaustion levels and reduced functional diversity of $\mathrm{T}$ cells in peripheral blood may predict severe progression in COVID-19 patients. Cell. Mol. Immunol. 2020, 17, 541-543. [CrossRef]

53. Liu, J.; Li, S.; Liu, J.; Liang, B.; Wang, X.; Wang, H.; Li, W.; Tong, Q.; Yi, J.; Zhao, L.; et al. Longitudinal characteristics of lymphocyte responses and cytokine profiles in the peripheral blood of SARS-CoV-2 infected patients. EBioMedicine 2020, 55, 102763. [CrossRef] [PubMed]

54. Han, M.; Xu, M.; Zhang, Y.; Liu, Z.; Li, S.; He, T.; Li, J.; Gao, Y.; Liu, W.; Li, T.; et al. Assessing SARS-CoV-2 RNA levels and lymphocyte/T cell counts in COVID-19 patients revealed initial immune status as a major determinant of disease severity. Med. Microbiol. Immunol. 2020, 209, 657-668. [CrossRef] [PubMed]

55. Kalicińska, E.; Szymczak, D.; Zińczuk, A.; Adamik, B.; Smiechowicz, J.; Skalec, T.; Nowicka-Suszko, D.; Biernat, M.; BoguckaFedorczuk, A.; Rybka, J.; et al. Immunosuppression as a Hallmark of Critical COVID-19: Prospective Study. Cells 2021, 10, 1293. [CrossRef]

56. Thieme, C.J.; Anft, M.; Paniskaki, K.; Blazquez-Navarro, A.; Doevelaar, A.; Seibert, F.S.; Hoelzer, B.; Konik, M.J.; Berger, M.M.; Brenner, T.; et al. Robust T Cell Response Toward Spike, Membrane, and Nucleocapsid SARS-CoV-2 Proteins Is Not Associated with Recovery in Critical COVID-19 Patients. Cell Rep. Med. 2020, 1, 100092. [CrossRef]

57. Dan, J.M.; Mateus, J.; Kato, Y.; Hastie, K.M.; Yu, E.D.; Faliti, C.E.; Grifoni, A.; Ramirez, S.I.; Haupt, S.; Frazier, A.; et al. Immunological memory to SARS-CoV-2 assessed for up to 8 months after infection. Science 2021, 371, eabf4063. [CrossRef]

58. Orologas-Stavrou, N.; Politou, M.; Rousakis, P.; Kostopoulos, I.V.; Ntanasis-Stathopoulos, I.; Jahaj, E.; Tsiligkeridou, E.; Gavriatopoulou, M.; Kastritis, E.; Kotanidou, A.; et al. Peripheral blood immune profiling of convalescent plasma donors reveals alterations in specific immune subpopulations even at 2 months post sars-cov-2 infection. Viruses 2021, 13, 26. [CrossRef]

59. Phadke, V.K.; Scanlon, N.; Jordan, S.C.; Rouphael, N.G. Immune Responses to SARS-CoV-2 in Solid Organ Transplant Recipients. Curr. Transplant. Rep. 2021, 8, 127-139. [CrossRef]

60. Favà, A.; Donadeu, L.; Sabé, N.; Pernin, V.; González-Costello, J.; Lladó, L.; Meneghini, M.; Charmetant, X.; García-Romero, E.; Cachero, A.; et al. SARS-CoV-2-specific serological and functional T cell immune responses during acute and early COVID-19 convalescence in solid organ transplant patients. Am. J. Transplant. 2021, 21, 2749-2761. [CrossRef]

61. Candon, S.; Guerrot, D.; Drouot, L.; Lemoine, M.; Lebourg, L.; Hanoy, M.; Boyer, O.; Bertrand, D. T cell and antibody responses to SARS-CoV-2: Experience from a French transplantation and hemodialysis center during the COVID-19 pandemic. Am. J. Transplant. 2021, 21, 854-863. [CrossRef] [PubMed]

62. Hartzell, S.; Bin, S.; Benedetti, C.; Haverly, M.; Gallon, L.; Zaza, G.; Riella, L.V.; Menon, M.C.; Florman, S.; Rahman, A.H.; et al. Evidence of potent humoral immune activity in COVID-19-infected kidney transplant recipients. Am. J. Transplant. 2020, 20, 3149-3161. [CrossRef]

63. Fernández-Ruiz, M.; Olea, B.; Giménez, E.; Laguna-Goya, R.; Trujillo, H.; Caravaca-Fontán, F.; Gutiérrez, E.; López-Medrano, F.; Remigia, M.J.; Almendro-Vazquez, P.; et al. SARS-CoV-2-Specific Cell-Mediated Immunity in Kidney Transplant Recipients Recovered from COVID-19. Transplantation 2021. [CrossRef]

64. Long, Q.X.; Liu, B.Z.; Deng, H.J.; Wu, G.C.; Deng, K.; Chen, Y.K.; Liao, P.; Qiu, J.F.; Lin, Y.; Cai, X.F.; et al. Antibody responses to SARS-CoV-2 in patients with COVID-19. Nat. Med. 2020, 26, 845-848. [CrossRef]

65. Dispinseri, S.; Secchi, M.; Pirillo, M.F.; Tolazzi, M.; Borghi, M.; Brigatti, C.; De Angelis, M.L.; Baratella, M.; Bazzigaluppi, E.; Venturi, G.; et al. Neutralizing antibody responses to SARS-CoV-2 in symptomatic COVID-19 is persistent and critical for survival. Nat. Commun. 2021, 12, 2670. [CrossRef] [PubMed]

66. Ju, B.; Zhang, Q.; Ge, J.; Wang, R.; Sun, J.; Ge, X.; Yu, J.; Shan, S.; Zhou, B.; Song, S.; et al. Human neutralizing antibodies elicited by SARS-CoV-2 infection. Nature 2020, 584, 115-119. [CrossRef]

67. Marinelli, T.; Ferreira, V.H.; Ierullo, M.; Ku, T.; Lilly, L.; Kim, S.J.; Schiff, J.; Sidhu, A.; McDonald, M.; Hosseini-Moghaddam, S.M.; et al. Prospective Clinical, Virologic, and Immunologic Assessment of COVID-19 in Transplant Recipients. Transplantation 2021. [CrossRef]

68. Caballero-Marcos, A.; Salcedo, M.; Alonso-Fernández, R.; Rodríguez-Perálvarez, M.; Olmedo, M.; Graus Morales, J.; CuervasMons, V.; Cachero, A.; Loinaz-Segurola, C.; Iñarrairaegui, M.; et al. Changes in humoral immune response after SARS-CoV-2 infection in liver transplant recipients compared to immunocompetent patients. Am. J. Transplant. 2021. [CrossRef] [PubMed]

69. Thieme, C.J.; Anft, M.; Paniskaki, K.; Blazquez-Navarro, A.; Doevelaar, A.; Seibert, F.S.; Hoelzer, B.; Konik, M.J.; Meister, T.L.; Pfaender, S.; et al. The Magnitude and Functionality of SARS-CoV-2 Reactive Cellular and Humoral Immunity in Transplant Population Is Similar to the General Population Despite Immunosuppression. Transplantation 2021. [CrossRef]

70. Cevik, M.; Tate, M.; Lloyd, O.; Maraolo, A.E.; Schafers, J.; Ho, A. SARS-CoV-2, SARS-CoV, and MERS-CoV viral load dynamics, duration of viral shedding, and infectiousness: A systematic review and meta-analysis. Lancet Microbe 2021, 2, e13-e22. [CrossRef]

71. Zhu, L.; Gong, N.; Liu, B.; Lu, X.; Chen, D.; Chen, S.; Shu, H.; Ma, K.; Xu, X.; Guo, Z.; et al. Coronavirus Disease 2019 Pneumonia in Immunosuppressed Renal Transplant Recipients: A Summary of 10 Confirmed Cases in Wuhan, China. Eur. Urol. 2020, 77, 748-754. [CrossRef] [PubMed]

72. Epstein, R.L.; Sperring, H.; Hofman, M.; Lodi, S.; White, L.F.; Barocas, J.A.; Bouton, T.C.; Xiao, Y.; Hsu, H.E.; Miller, N.S.; et al. Time to SARS-CoV-2 PCR Clearance in Immunocompromising Conditions: Is Test-Based Removal From Isolation Necessary in Severely Immunocompromised Individuals? Open Forum Infect. Dis. 2021, 8, ofab164. [CrossRef] [PubMed]

73. Corey, L.; Beyrer, C.; Cohen, M.S.; Michael, N.L.; Bedford, T.; Rolland, M. SARS-CoV-2 Variants in Patients with Immunosuppression. N. Engl. J. Med. 2021, 385, 562-566. [CrossRef] [PubMed] 
74. Laracy, J.C.; Miko, B.A.; Pereira, M.R. The solid organ transplant recipient with SARS-CoV-2 infection. Curr. Opin. Organ Transplant. 2021. Publish Ahead of Print. [CrossRef] [PubMed]

75. Alam, S.; Kamal, T.B.; Sarker, M.M.R.; Zhou, J.-R.; Rahman, S.M.A.; Mohamed, I.N. Therapeutic Effectiveness and Safety of Repurposing Drugs for the Treatment of COVID-19: Position Standing in 2021. Front. Pharmacol. 2021, 12, 659577. [CrossRef] [PubMed]

76. Kaka, A.S.; MacDonald, R.; Greer, N.; Vela, K.; Duan-Porter, W.; Obley, A.; Wilt, T.J. Major Update: Remdesivir for Adults With COVID-19: A Living Systematic Review and Meta-analysis for the American College of Physicians Practice Points. Ann. Intern. Med. 2021, 174, 663-672. [CrossRef]

77. Lamontagne, F.; Agoritsas, T.; Siemieniuk, R.; Rochwerg, B.; Bartoszko, J.; Askie, L.; MacDonald, H.; Amin, W.; Bausch, F.J.; Burhan, E.; et al. A living WHO guideline on drugs to prevent covid-19. BMJ 2021, 372, n526. [CrossRef]

78. Meshram, H.S.; Kute, V.B.; Patel, H.; Banerjee, S.; Navadiya, V.; Desai, S.; Rizvi, S.J.; Mishra, V.; Chauhan, S. Feasibility and safety of remdesivir in SARS-CoV2 infected renal transplant recipients: A retrospective cohort from a developing nation. Transpl. Infect. Dis. 2021. [CrossRef]

79. Buxeda, A.; Arias-Cabrales, C.; Pérez-Sáez, M.J.; Cacho, J.; Pelegrin, S.C.; Melilli, E.; Aladrén, M.J.; Galeano, C.; Lorenzo, I.; Mazuecos, A.; et al. Use and safety of remdesivir in kidney transplant recipients with COVID-19. Kidney Int. Rep. 2021. [CrossRef]

80. Elec, A.D.; Oltean, M.; Goldis, P.; Cismaru, C.; Lupse, M.; Muntean, A.; Elec, F.I. COVID-19 after kidney transplantation: Early outcomes and renal function following antiviral treatment. Int. J. Infect. Dis. 2021, 104, 426-432. [CrossRef]

81. Jamir, I.; Lohia, P.; Pande, R.K.; Setia, R.; Singhal, A.K.; Chaudhary, A. Convalescent plasma therapy and remdesivir duo successfully salvaged an early liver transplant recipient with severe COVID-19 pneumonia. Ann. Hepato-Biliary-Pancreatic Surg. 2020, 24, 526-532. [CrossRef]

82. Mohseni, M.; Albus, M.; Kaminski, A.; Harrison, M.F. A Case of COVID-19 Re-Infection in a Liver Transplant Patient. Cureus 2021, 13, e14916. [CrossRef]

83. Schreiber, A.; Elango, K.; Hong, K.; Ahsan, C. Cardiac transplant recipient with COVID-19 induced acute hypoxic respiratory failure: A case report. Eur. Hear. J.-Case Rep. 2021, 5, ytab217. [CrossRef] [PubMed]

84. Ballout, J.A.; Ahmed, T.; Kolodziej, A.R. COVID-19 and Heart Transplant: A Case Series and Review of the Literature. Transplant. Proc. 2021, 53, 1219-1223. [CrossRef] [PubMed]

85. Rizzo, E. Ivermectin, antiviral properties and COVID-19: A possible new mechanism of action. Naunyn. Schmiedebergs. Arch. Pharmacol. 2020, 393, 1153-1156. [CrossRef]

86. Patterson, B.K.; Guevara-Coto, J.; Yogendra, R.; Francisco, E.B.; Long, E.; Pise, A.; Rodrigues, H.; Parikh, P.; Mora, J.; MoraRodríguez, R.A. Immune-Based Prediction of COVID-19 Severity and Chronicity Decoded Using Machine Learning. Front. Immunol. 2021, 12, 700782. [CrossRef]

87. Fernández-Ruiz, M.; Aguado, J.M. Immunomodulatory Therapies for COVID-19 in Solid Organ Transplant Recipients. Curr. Transplant. Rep. 2020, 7, 379-389. [CrossRef]

88. Kino, T.; Burd, I.; Segars, J.H. Dexamethasone for severe covid-19: How does it work at cellular and molecular levels? Int. J. Mol. Sci. 2021, 22, 6764. [CrossRef] [PubMed]

89. Li, H.P.; He, X.; Zhang, L.; Li, C.X.; Li, S.Q.; Li, Q.Y. Therapeutic Agents Rounding Up the Immunopathology of COVID-19. Ther. Clin. Risk Manag. 2021, 17, 657-668. [CrossRef]

90. Horby, P.; Lim, W.S.; Emberson, J.R.; Mafham, M.; Bell, J.L.; Linsell, L.; Staplin, N.; Brightling, C.; Ustianowski, A.; Elmahi, E.; et al. Dexamethasone in Hospitalized Patients with Covid-19. N. Engl. J. Med. 2021, 384, 693-704. [CrossRef]

91. Aversa, M.; Benvenuto, L.; Anderson, M.; Shah, L.; Robbins, H.; Pereira, M.; Scheffert, J.; Carroll, M.; Hum, J.; Nolan, M.; et al. COVID-19 in lung transplant recipients: A single center case series from New York City. Am. J. Transplant. 2020, 20, 3072-3080. [CrossRef]

92. Brugiere, O.; Neuville, M.; Le Balch, P.; Le Tulzo, Y.; Brun, A.-L.; Hamid, A.; Beaumont, L.; Roux, A.; Jouneau, S.; Parquin, F. COVID-19 in Lung Transplant Recipients: 2 Cases With Acute Respiratory Distress Syndrome Successfully Treated With High-Dose Corticosteroids. Exp. Clin. Transplant. 2021. [CrossRef] [PubMed]

93. Alunno, A.; Najm, A.; Mariette, X.; De Marco, G.; Emmel, J.; Mason, L.; McGonagle, D.G.; MacHado, P.M. Immunomodulatory therapies for SARS-CoV-2 infection: A systematic literature review to inform EULAR points to consider. Ann. Rheum. Dis. 2021, 80, 803-815. [CrossRef]

94. Dale, M.; Sogawa, H.; Seyedsaadat, S.M.; Wolf, D.C.; Bodin, R.; Partiula, B.; Nog, R.; Latifi, R.; John, D.; Veillette, G.; et al. Successful Management of COVID-19 Infection in 2 Early Post-Liver Transplant Recipients. Transplant. Proc. 2021, 53, 1175-1179. [CrossRef]

95. Rabaan, A.A.; Al-Ahmed, S.H.; Muhammad, J.; Khan, A.; Sule, A.A.; Tirupathi, R.; Mutair, A.A.; Alhumaid, S.; Al-Omari, A.; Dhawan, M.; et al. Role of inflammatory cytokines in covid-19 patients: A review on molecular mechanisms, immune functions, immunopathology and immunomodulatory drugs to counter cytokine storm. Vaccines 2021, 9, 436. [CrossRef] [PubMed]

96. Gubernatorova, E.O.; Gorshkova, E.A.; Polinova, A.I.; Drutskaya, M.S. IL-6: Relevance for immunopathology of SARS-CoV-2. Cytokine Growth Factor Rev. 2020, 53, 13-24. [CrossRef] [PubMed]

97. Masiá, M.; Fernández-González, M.; Padilla, S.; Ortega, P.; García, J.A.; Agulló, V.; García-Abellán, J.; Telenti, G.; Guillén, L.; Gutiérrez, F. Impact of interleukin-6 blockade with tocilizumab on SARS-CoV-2 viral kinetics and antibody responses in patients with COVID-19: A prospective cohort study. EBioMedicine 2020, 60, 102999. [CrossRef] 
98. Roche. Roche Provides an Update on the Phase III COVACTA Trial of Actemra/RoActemra in Hospitalised Patients with Severe COVID-19 Associated Pneumonia. Available online: https://www.roche.com/investors/updates/inv-update-2020-07-29.htm (accessed on 16 July 2021).

99. Sanofi and Regeneron Provide Update on Kevzara®(sarilumab) Phase 3 U.S. Trial in COVID-19 Patients-Sanofi. Available online: https:/ / www.sanofi.com/en/media-room/press-releases/2020/2020-07-02-22-30-00 (accessed on 16 July 2021).

100. Moreno-García, E.; Rico, E.; Albiach, L.; Agüero, D.; Ambrosioni, J.; Bodro, M.; Cardozo, C.; Chumbita, M.; De la Mora, M.; García-Pouton, N.; et al. Tocilizumab reduces the risk of ICU admission and mortality in patients with SARS-CoV-2 infection. Rev. Esp. Quimioter. 2021, 34, 238-244. [CrossRef]

101. Ghosn, L.; Chaimani, A.; Evrenoglou, T.; Davidson, M.; Graña, C.; Schmucker, C.; Bollig, C.; Henschke, N.; Sguassero, Y.; Nejstgaard, C.H.; et al. Interleukin-6 blocking agents for treating COVID-19: A living systematic review. Cochrane Database Syst. Rev. 2021, 2021, CD013881. [CrossRef]

102. Christensen, J.; Kumar, D.; Moinuddin, I.; Bryson, A.; Kashi, Z.; Kimball, P.; Levy, M.; Kamal, L.; King, A.; Gupta, G. Coronavirus Disease 2019 Viremia, Serologies, and Clinical Course in a Case Series of Transplant Recipients. Transplant. Proc. 2020, 52, 2637-2641. [CrossRef]

103. Cavalli, G.; De Luca, G.; Campochiaro, C.; Della-Torre, E.; Ripa, M.; Canetti, D.; Oltolini, C.; Castiglioni, B.; Tassan Din, C.; Boffini, N.; et al. Interleukin-1 blockade with high-dose anakinra in patients with COVID-19, acute respiratory distress syndrome, and hyperinflammation: A retrospective cohort study. Lancet Rheumatol. 2020, 2, e325-e331. [CrossRef]

104. Cauchois, R.; Koubi, M.; Delarbre, D.; Manet, C.; Carvelli, J.; Blasco, V.B.; Jean, R.; Fouche, L.; Bornet, C.; Pauly, V.; et al. Early IL-1 receptor blockade in severe inflammatory respiratory failure complicating COVID-19. Proc. Natl. Acad. Sci. USA 2020, 117, 18951-18953. [CrossRef] [PubMed]

105. Huet, T.; Beaussier, H.; Voisin, O.; Jouveshomme, S.; Dauriat, G.; Lazareth, I.; Sacco, E.; Naccache, J.M.; Bézie, Y.; Laplanche, S.; et al. Anakinra for severe forms of COVID-19: A cohort study. Lancet Rheumatol. 2020, 2, e393-e400. [CrossRef]

106. Aouba, A.; Baldolli, A.; Geffray, L.; Verdon, R.; Bergot, E.; Martin-Silva, N.; Justet, A. Targeting the inflammatory cascade with anakinra in moderate to severe COVID-19 pneumonia: Case series. Ann. Rheum. Dis. 2020, 79, 1381-1382. [CrossRef] [PubMed]

107. Somagutta, M.K.R.; Lourdes Pormento, M.K.; Hamid, P.; Hamdan, A.; Khan, M.A.; Desir, R.; Vijayan, R.; Shirke, S.; Jeyakumar, R.; Dogar, Z.; et al. The Safety and Efficacy of Anakinra, an Interleukin-1 Antagonist in Severe Cases of COVID-19: A Systematic Review and Meta-Analysis. Infect. Chemother. 2021, 53, 221. [CrossRef]

108. Yuksel, M.; Akturk, H.; Mizikoglu, O.; Toroslu, E.; Arikan, C. A single-center report of COVID-19 disease course and management in liver transplanted pediatric patients. Pediatr. Transplant. 2021. [CrossRef]

109. Bodro, M.; Cofan, F.; Ríos, J.; Herrera, S.; Linares, L.; Marcos, M.A.; Soriano, A.; Moreno, A.; Diekmann, F. Use of Anti-Cytokine Therapy in Kidney Transplant Recipients with COVID-19. J. Clin. Med. 2021, 10, 1551. [CrossRef]

110. Stallmach, A.; Kortgen, A.; Gonnert, F.; Coldewey, S.M.; Reuken, P.; Bauer, M. Infliximab against severe COVID-19-induced cytokine storm syndrome with organ failure-A cautionary case series. Crit. Care 2020, 24, 444. [CrossRef]

111. Honore, P.M.; Barreto Gutierrez, L.; Kugener, L.; Redant, S.; Attou, R.; Gallerani, A.; De Bels, D. Infliximab can reduce mortality from 35 to $14 \%$ in critically ill patients with COVID-19: Perhaps some potential confounders to consider. Crit. Care 2020, 24, 603. [CrossRef]

112. Ray, K. Antibody responses to SARS-CoV-2 infection are attenuated in infliximab-treated patients with IBD. Nat. Rev. Gastroenterol. Hepatol. 2021, 18, 286. [CrossRef]

113. Sarmiento, M.; Rojas, P.; Jerez, J.; Bertín, P.; Campbell, J.; García, M.J.; Pereira, J.; Triantafilo, N.; Ocqueteau, M. Ruxolitinib for Severe COVID-19-Related Hyperinflammation in Nonresponders to Steroids. Acta Haematol. 2021, 1-7. [CrossRef]

114. Cantini, F.; Niccoli, L.; Nannini, C.; Matarrese, D.; Di Natale, M.E.; Lotti, P.; Aquilini, D.; Landini, G.; Cimolato, B.; Di Pietro, M.A.; et al. Beneficial impact of Baricitinib in COVID-19 moderate pneumonia; multicentre study. J. Infect. 2020, 81, 647-679. [CrossRef]

115. Chen, C.X.; Wang, J.J.; Li, H.; Yuan, L.T.; Gale, R.P.; Liang, Y. JAK-inhibitors for coronavirus disease-2019 (COVID-19): A meta-analysis. Leukemia 2021. [CrossRef]

116. Channappanavar, R.; Fehr, A.R.; Zheng, J.; Wohlford-Lenane, C.; Abrahante, J.E.; Mack, M.; Sompallae, R.; McCray, P.B.; Meyerholz, D.K.; Perlman, S. IFN-I response timing relative to virus replication determines MERS coronavirus infection outcomes. J. Clin. Investig. 2019, 129, 3625-3639. [CrossRef]

117. Ziegler, C.G.K.; Allon, S.J.; Nyquist, S.K.; Mbano, I.M.; Miao, V.N.; Tzouanas, C.N.; Cao, Y.; Yousif, A.S.; Bals, J.; Hauser, B.M.; et al. SARS-CoV-2 Receptor ACE2 Is an Interferon-Stimulated Gene in Human Airway Epithelial Cells and Is Detected in Specific Cell Subsets across Tissues. Cell 2020, 181, 1016-1035.e19. [CrossRef] [PubMed]

118. Yin, P.; Meng, J.; Chen, J.; Gao, J.; Wang, D.; Liu, S.; Guo, Q.; Zhu, M.; Zhang, G.; Liu, Y.; et al. Antiviral drugs arbidol and interferon alpha-1b contribute to reducing the severity of COVID-19 patients: A retrospective cohort study. Virol. J. 2021, 18, 1-11. [CrossRef]

119. Davoudi-Monfared, E.; Rahmani, H.; Khalili, H.; Hajiabdolbaghi, M.; Salehi, M.; Abbasian, L.; Kazemzadeh, H.; Yekaninejad, M.S. A randomized clinical trial of the efficacy and safety of interferon $\beta-1 \mathrm{a}$ in treatment of severe COVID-19. Antimicrob. Agents Chemother. 2020, 64, e01061-20. [CrossRef]

120. Nakhlband, A.; Fakhari, A.; Azizi, H. Interferon-alpha position in combating with COVID-19: A systematic review. J. Med. Virol. 2021. [CrossRef] 
121. Todorović-Raković, N.; Whitfield, J.R. Between immunomodulation and immunotolerance: The role of IFN $\gamma$ in SARS-CoV-2 disease. Cytokine 2021, 146, 155637. [CrossRef]

122. Ramasamy, S.; Subbian, S. Critical determinants of cytokine storm and type i interferon response in COVID-19 pathogenesis. Clin. Microbiol. Rev. 2021, 34, e00299-20. [CrossRef]

123. Myasnikov, A.L.; Berns, S.A.; Zverev, K.V.; Lartseva, O.A.; Talyzin, P.A. Efficacy of interferon gamma in the prevention of sars-cov-2 infection (Covid-19): Results of a prospective controlled trial. Int. J. Biomed. 2020, 10, 182-188. [CrossRef]

124. Myasnikov, A.L.Z.; Berns, S.A.; Talyzin, P.A.; Ershov, F.I. Interferon gamma in the treatment of patients with moderate COVID-19. Vopr. Virusol. 2021, 66, 47-54. [CrossRef] [PubMed]

125. Simonovich, V.A.; Burgos Pratx, L.D.; Scibona, P.; Beruto, M.V.; Vallone, M.G.; Vázquez, C.; Savoy, N.; Giunta, D.H.; Pérez, L.G.; Sánchez, M. del L.; et al. A Randomized Trial of Convalescent Plasma in Covid-19 Severe Pneumonia. N. Engl. J. Med. 2021, 384, 619-629. [CrossRef] [PubMed]

126. Wardhani, S.O.; Fajar, J.K.; Wulandari, L.; Soegiarto, G.; Purnamasari, Y.; Asmiragani, A.; Maliga, H.A.; Ilmawan, M.; Seran, G.; Iskandar, D.S.; et al. Association between convalescent plasma and the risk of mortality among patients with COVID-19: A meta-analysis. F1000Research 2021, 10, 64. [CrossRef] [PubMed]

127. Czogalla, J.; Schmidt-lauber, C.; Peine, S.; Kluger, M.A.; Schmiedel, S.; Bangert, K.; Kluge, S.; Huber, S.; Victor, G.; Huber, T.B.; et al. Convalescent plasma treatment for early post-kidney transplant acquired COVID-19. Transpl. Infect. Dis. 2021, 23, 5-9. [CrossRef]

128. Ganesh, R.; Philpot, L.M.; Bierle, D.M.; Anderson, R.J.; Arndt, L.L.; Arndt, R.F.; Culbertson, T.L.; Destro Borgen, M.J.; Hanson, S.N.; Kennedy, B.D.; et al. Real-World Clinical Outcomes of Bamlanivimab and Casirivimab-Imdevimab among High-Risk Patients with Mild to Moderate Coronavirus Disease 2019. J. Infect. Dis. 2021. [CrossRef] [PubMed]

129. Del Bello, A.; Marion, O.; Vellas, C.; Faguer, S.; Izopet, J.; Kamar, N. Anti-SARS-Cov-2 Monoclonal Antibodies in Solid-OrganTransplant Patients. Transplantation 2021. [CrossRef]

130. Moosavi, S.A.; Mashhadiagha, A.; Motazedian, N.; Hashemazar, A.; Hoveidaei, A.H.; Bolignano, D. COVID-19 clinical manifestations and treatment strategies among solid-organ recipients: A systematic review of cases. Transpl. Infect. Dis. 2020, 22, e13427. [CrossRef]

131. Coll, E.; Fernández-Ruiz, M.; Padilla, M.; Moreso, F.; Hernández-Vicente, A.; Yañez, I.; Molina, M.; Vázquez-Sánchez, T.; Crespo, M.; Facundo, C.; et al. COVID-19 in Solid Organ Transplant Recipients in Spain Throughout 2020. Transplantation 2021. [CrossRef]

132. Gut, G.; Góral, A.; Dal Canton, Z.; Poznański, P.; Krajewska, M.; Kusztal, M. Kidney Transplantation in COVID Pandemic-A Review of Guidelines. J. Clin. Med. 2021, 10, 2877. [CrossRef]

133. Danziger-Isakov, L.; Blumberg, E.A.; Manuel, O.; Sester, M. Impact of COVID-19 in solid organ transplant recipients. Am. J. Transplant. 2021, 21, 925-937. [CrossRef]

134. Klein, J.; Brito, A.; Trubin, P.; Lu, P.; Wong, P.; Alpert, T.; Pena-Hernandez, M.; Haynes, W.; Kamath, K.; Liu, F.; et al. Longitudinal immune profiling of a SARS-CoV-2 reinfection in a solid organ transplant recipient. Res. Sq. 2021. [CrossRef]

135. Karam, B.S.; Morris, R.S.; Bramante, C.T.; Puskarich, M.; Zolfaghari, E.J.; Lotfi-Emran, S.; Ingraham, N.E.; Charles, A.; Odde, D.J.; Tignanelli, C.J. mTOR inhibition in COVID-19: A commentary and review of efficacy in RNA viruses. J. Med. Virol. 2021, 93, 1843-1846. [CrossRef] [PubMed]

136. Rodriguez-Cubillo, B.; de la Higuera, M.A.M.; Lucena, R.; Franci, E.V.; Hurtado, M.; Romero, N.C.; Moreno, A.R.; Valencia, D.; Velo, M.; Fornie, I.S.; et al. Should cyclosporine be useful in renal transplant recipients affected by SARS-CoV-2? Am. J. Transplant. 2020, 20, 3173-3181. [CrossRef]

137. Belli, L.S.; Fondevila, C.; Cortesi, P.A.; Conti, S.; Karam, V.; Adam, R.; Coilly, A.; Ericzon, B.G.; Loinaz, C.; Cuervas-Mons, V.; et al. Protective Role of Tacrolimus, Deleterious Role of Age and Comorbidities in Liver Transplant Recipients With Covid-19: Results From the ELITA/ELTR Multi-center European Study. Gastroenterology 2021, 160, 1151-1163.e3. [CrossRef]

138. Karruli, A.; Spiezia, S.; Boccia, F.; Gagliardi, M.; Patauner, F.; Salemme, A.; Maiello, C.; Zampino, R.; Durante-Mangoni, E. Effect of immunosuppression maintenance in solid organ transplant recipients with COVID-19: Systematic review and meta-analysis. Transpl. Infect. Dis. 2021. [CrossRef]

139. Mirjalili, M.; Shafiekhani, M.; Vazin, A. Coronavirus disease 2019 (COVID-19) and transplantation: Pharmacotherapeutic management of immunosuppression regimen. Ther. Clin. Risk Manag. 2020, 16, 617-629. [CrossRef] [PubMed]

140. Oguz, E.G.; Atilgan, K.G.; Cimen, S.G.; Sahin, H.; Selen, T.; Ebinc, F.A.; Cimen, S.; Ayli, M.D. COVID-19 infection in a kidney transplant recipient-special emphasis on pharmacokinetic interactions: A case report. World J. Transplant. 2020, 10, 365-371. [CrossRef]

141. Polack, F.P.; Thomas, S.J.; Kitchin, N.; Absalon, J.; Gurtman, A.; Lockhart, S.; Perez, J.L.; Pérez Marc, G.; Moreira, E.D.; Zerbini, C.; et al. Safety and Efficacy of the BNT162b2 mRNA Covid-19 Vaccine. N. Engl. J. Med. 2020, 383, 2603-2615. [CrossRef]

142. Heldman, M.R.; Limaye, A.P. SARS-CoV-2 vaccines in kidney transplant recipients: Will they be safe and effective and how will we know? J. Am. Soc. Nephrol. 2021, 32, 1021-1024. [CrossRef]

143. Carr, E.J.; Kronbichler, A.; Graham-Brown, M.; Abra, G.; Argyropoulos, C.; Harper, L.; Lerma, E.V.; Suri, R.S.; Topf, J.; Willicombe, M.; et al. Systematic Review of Early Immune Response to SARS-CoV-2 Vaccination Among Patients with Chronic Kidney Disease. Kidney Int. Rep. 2021. [CrossRef] [PubMed]

144. Jiang, S.; Hillyer, C.; Du, L. Neutralizing Antibodies against SARS-CoV-2 and Other Human Coronaviruses. Trends Immunol. 2020, 41, 355-359. [CrossRef] [PubMed] 
145. Jakuszko, K.; Kościelska-Kasprzak, K.; Żabińska, M.; Bartoszek, D.; Poznański, P.; Rukasz, D.; Kłak, R.; Królak-Olejnik, B.; Krajewska, M. Immune Response to Vaccination against COVID-19 in Breastfeeding Health Workers. Vaccines $2021,9,663$. [CrossRef] [PubMed]

146. Rincon-Arevalo, H.; Choi, M.; Stefanski, A.L.; Halleck, F.; Weber, U.; Szelinski, F.; Jahrsdörfer, B.; Schrezenmeier, H.; Ludwig, C.; Sattler, A.; et al. Impaired humoral immunity to SARS-CoV-2 BNT162b2 vaccine in kidney transplant recipients and dialysis patients. Sci. Immunol. 2021, 6, eabj1031. [CrossRef] [PubMed]

147. Korth, J.; Jahn, M.; Dorsch, O.; Anastasiou, O.E.; Sorge-Hädicke, B.; Eisenberger, U.; Gäckler, A.; Dittmer, U.; Witzke, O.; Wilde, B.; et al. Impaired humoral response in renal transplant recipients to sars-cov-2 vaccination with bnt162b2 (Pfizer-biontech). Viruses 2021, 13, 756. [CrossRef]

148. Grupper, A.; Rabinowich, L.; Schwartz, D.; Schwartz, I.F.; Ben-Yehoyada, M.; Shashar, M.; Katchman, E.; Halperin, T.; Turner, D.; Goykhman, Y.; et al. Reduced humoral response to mRNA SARS-CoV-2 BNT162b2 vaccine in kidney transplant recipients without prior exposure to the virus. Am. J. Transplant. 2021, 21, 2719-2726. [CrossRef]

149. Benotmane, I.; Gautier-Vargas, G.; Cognard, N.; Olagne, J.; Heibel, F.; Braun-Parvez, L.; Martzloff, J.; Perrin, P.; Moulin, B.; Fafi-Kremer, S.; et al. Low immunization rates among kidney transplant recipients who received 2 doses of the mRNA-1273 SARS-CoV-2 vaccine. Kidney Int. 2021, 99, 1498-1500. [CrossRef]

150. Boyarsky, B.J.; Werbel, W.A.; Avery, R.K.; Tobian, A.A.R.; Massie, A.B.; Segev, D.L.; Garonzik-Wang, J.M. Immunogenicity of a Single Dose of SARS-CoV-2 Messenger RNA Vaccine in Solid Organ Transplant Recipients. JAMA—J. Am. Med. Assoc. 2021, 325, 1784-1786. [CrossRef]

151. Yi, S.G.; Knight, R.J.; Graviss, E.A.; Nguyen, D.T.; Ghobrial, R.M.; Gaber, A.O.; Huang, H.J. Kidney Transplant Recipients Rarely Show an Early Antibody Response Following the First COVID-19 Vaccine Administration. Transplantation 2021. Publish Ahead of Print. [CrossRef] [PubMed]

152. Benotmane, I.; Gautier-Vargas, G.; Cognard, N.; Olagne, J.; Heibel, F.; Braun-Parvez, L.; Martzloff, J.; Perrin, P.; Moulin, B.; Fafi-Kremer, S.; et al. Weak anti-SARS-CoV-2 antibody response after the first injection of an mRNA COVID-19 vaccine in kidney transplant recipients. Kidney Int. 2021, 99, 1487-1489. [CrossRef]

153. Kamar, N.; Abravanel, F.; Marion, O.; Couat, C.; Izopet, J.; Del Bello, A. Three Doses of an mRNA Covid-19 Vaccine in Solid-Organ Transplant Recipients. N. Engl. J. Med. 2021. [CrossRef]

154. Werbel, W.A.; Boyarsky, B.J.; Ou, M.T.; Massie, A.B.; Tobian, A.A.R.; Garonzik-Wang, J.M.; Segev, D.L. Safety and Immunogenicity of a Third Dose of SARS-CoV-2 Vaccine in Solid Organ Transplant Recipients: A Case Series. Ann. Intern. Med. 2021. [CrossRef]

155. Fairhead, T.; Hendren, E.; Tinckam, K.; Rose, C.; Sherlock, C.H.; Shi, L.; Crowcroft, N.S.; Gubbay, J.B.; Landsberg, D.; Knoll, G.; et al. Poor seroprotection but allosensitization after adjuvanted pandemic influenza H1N1 vaccine in kidney transplant recipients. Transpl. Infect. Dis. 2012, 14, 575-583. [CrossRef] [PubMed]

156. Felldin, M.; Studahl, M.; Svennerholm, B.; Friman, V. The antibody response to pandemic H1N1 2009 influenza vaccine in adult organ transplant patients. Transpl. Int. 2012, 25, 166-171. [CrossRef] [PubMed]

157. Rondaan, C.; de Joode, A.A.E.; Wang, L.; Siderius, M.; Raveling-Eelsing, E.; van Leer-Buter, C.; van Assen, S.; Bos, N.A.; Westra, J. Immune response to varicella-zoster virus before and after renal transplantation. Antiviral Res. 2020, 183, 104938. [CrossRef]

158. Jarque, M.; Crespo, E.; Melilli, E.; Gutiérrez, A.; Moreso, F.; Guirado, L.; Revuelta, I.; Montero, N.; Torras, J.; Riera, L.; et al. Cellular Immunity to Predict the Risk of Cytomegalovirus Infection in Kidney Transplantation: A Prospective, Interventional, Multicenter Clinical Trial. Clin. Infect. Dis. 2020, 71, 2375-2385. [CrossRef]

159. Comoli, P.; Hirsch, H.H.; Ginevri, F. Cellular immune responses to BK virus. Curr. Opin. Organ Transplant. 2008, 13, 569-574. [CrossRef] [PubMed]

160. Murugesan, K.; Jagannathan, P.; Pham, T.D.; Pandey, S.; Bonilla, H.F.; Jacobson, K.; Parsonnet, J.; Andrews, J.R.; Weiskopf, D.; Sette, A.; et al. Interferon-gamma release assay for accurate detection of SARS-CoV-2 T cell response. Clin. Infect. Dis. 2020. [CrossRef]

161. Schwarzkopf, S.; Krawczyk, A.; Knop, D.; Klump, H.; Heinold, A.; Heinemann, F.M.; Thümmler, L.; Temme, C.; Breyer, M.; Witzke, O.; et al. Cellular Immunity in COVID-19 Convalescents with PCR-Confirmed Infection but with Undetectable SARS-CoV-2-Specific IgG. Emerg. Infect. Dis. 2021, 27, 122-129. [CrossRef]

162. Chavarot, N.; Ouedrani, A.; Marion, O.; Leruez-Ville, M.; Villain, E.; Baaziz, M.; Del Bello, A.; Burger, C.; Sberro-Soussan, R.; Martinez, F.; et al. Poor Anti-SARS-CoV-2 Humoral and T-cell Responses After 2 Injections of mRNA Vaccine in Kidney Transplant Recipients Treated with Belatacept. Transplantation 2021. [CrossRef]

163. Katerinis, I.; Hadaya, K.; Duquesnoy, R.; Ferrari-Lacraz, S.; Meier, S.; Van Delden, C.; Martin, P.Y.; Siegrist, C.A.; Villard, J. De novo anti-HLA antibody after pandemic H1N1 and seasonal influenza immunization in kidney transplant recipients. Am. J. Transplant. 2011, 11, 1727-1733. [CrossRef]

164. Schaffer, S.A.; Husain, S.; Delgado, D.H.; Kavanaugh, L.; Ross, H.J. Impact of adjuvanted H1N1 vaccine on cell-mediated rejection in heart transplant recipients. Am. J. Transplant. 2011, 11, 2751-2754. [CrossRef] [PubMed]

165. Kumar, D.; Campbell, P.; Hoschler, K.; Hidalgo, L.; Al-Dabbagh, M.; Wilson, L.; Humar, A. Randomized controlled trial of adjuvanted versus nonadjuvanted influenza vaccine in kidney transplant recipients. Transplantation 2016, 100, 662-669. [CrossRef] [PubMed]

166. Roberts, M.B.; Fishman, J.A. Immunosuppressive Agents and Infectious Risk in Transplantation: Managing the “Net State of Immunosuppression". Clin. Infect. Dis. 2020, ciaa1189. [CrossRef] [PubMed] 